\title{
THE STUDY OF CRINOIDS DURING THE 20TH CENTURY AND THE CHALLENGES OF THE 21ST CENTURY
}

\author{
WILLIAM I. AUSICH AND THOMAS W. KAMMER \\ Department of Geological Sciences, The Ohio State University, Columbus 43210, < ausich.1@osu.edu>; and \\ Department of Geology and Geography, West Virginia University, Morgantown 26506-6300, <tkammer@wvu.edu>
}

\begin{abstract}
Development of a phylogenetic classification has been a primary pursuit of crinoid paleontologists during the 20th century. Wachsmuth and Springer and Bather vigorously debated crinoid classification during the waning years of the 19th century, and although tremendous progress has been made a comprehensive phylogenetic classification is still the primary objective for crinoid research during the early 21 st century. Twentieth century crinoid studies are divisible into four periods. The direct influence of Frank Springer and Francis Bather continued until approximately 1925. Descriptive studies dominated the period of 1926-1943 and culminated in a comprehensive classification of Paleozoic crinoids that was a combination of the ideas of Wachsmuth and Springer and Bather. The end of the third period, 1944-1978, was marked by publication of the Treatise on Invertebrate Paleontology. The Treatise compilation brought together classification ideas for the entire class into a truly comprehensive classification, although problems remained with the phylogenetic underpinnings of the Treatise classification. During the third period, pioneering work on crinoid paleobiology laid the foundation for significant paleobiology advances for the fourth, 1979-1999, period. This last period also witnessed significant advances in the taxonomy of crinoid faunas at critical intervals, the taxonomy of crinoids from new geographic areas, and working toward the solution to the origin and early evolution of the Crinoidea.

Continued work on crinoids in the 21 st century promises to provide significant advances both for understanding the evolutionary history of crinoids and for understanding the history of epifaunal benthic communities through time. Immediate challenges include completion of a comprehensive phylogenetic classification, which will open the door for evolutionary paleoecologic and paleobiologic studies; utilization of computerized morphometric techniques in the analysis of functional morphology; systematic studies of new faunas in critical intervals; discovery of faunas in new geographic areas to better constrain knowledge of crinoid biogeography; and modern systematic revision of classic North American and European faunas.
\end{abstract}

\section{INTRODUCTION}

A CONTINUING THEME in crinoid systematics has been the struggle to create classification schemes based on presumed phylogenetic criteria as opposed to those merely phenetic. At the turn of the last century the phylogenetic content of classification schemes was being debated, as it is when we enter the 21 st century.

The two great crinoid paleontologists of the late nineteenth century and first quarter of the twentieth century, Frank Springer (1848-1927) and Francis A. Bather (1863-1934), neared completion of their scientific study of crinoids by 1925 . Despite the disagreements and unresolved debate (sometimes with considerable vigor, see below) on super-familial classification, when their careers were complete, the study of crinoids was in a remarkably robust state. The principal unfinished business in 1925 was settling the Springer-Bather debate on crinoid classification.

Twentieth century work on crinoids is readily divisible into four periods. As mentioned above, 1925 is a convenient break that approximately corresponds with the completion of the work of Springer and Bather, and 1925 was also within the publication renewal following World War I. The second period, 1926-1943, had a slightly increased level of work compared to 1900-1925. The publication of two benchmark studies in 1943, Moore and Laudon's, Evolution and Classification of Paleozoic Crinoids and Bassler and Moodey's, Bibliographic and Faunal Index of Paleozoic Pelmatozoan Echinoderms brought the second period of study to a close. The third period, 1944-1978, was characterized by the advent of paleobiologic approaches, such as functional morphology and paleoecology. It was completed by publication of the Treatise on Invertebrate Paleontology, Part T (Moore and Teichert, 1978). The fourth period includes from 1979 to the end of the century.

\section{CRINOID STUDIES 1900 TO 1925}

In order to understand the evolution of crinoid classification schemes during the early part of the 20th century, it is necessary to briefly review the state of the art at the end of the 19th century.
Charles Wachsmuth and Frank Springer had established their authority as crinoid experts with their series on "Revision of the Palaeocrinoidea" (1880, 1881, 1885, 1886). At that time all Paleozoic crinoids were thought to have a covered mouth and were grouped in the subclass Palaeocrinoidea, whereas Mesozoic and Cenozoic crinoids had an exposed mouth and were grouped in the subclass Neocrinoidea. Discovery of Paleozoic crinoids with exposed mouths (cyathocrine cladids and flexibles; note: all taxonomic names in parentheses follow Moore and Teichert, 1978) required abandonment of the Palaeocrinoidea-Neocrinoidea dichotomy, and in its place they proposed the subclasses Inadunata, Camerata, and Articulata (flexibles and articulates) (Wachsmuth and Springer, 1891, 1897) (Table 1). Also in their 1891 paper they spent 12 pages challenging Bather's (1890b) extensive revisions of their earlier classification of the Fistulata (disparids and cladids with an anal sac or tube). Thus began an acrimonious exchange of papers that lasted more than a decade and helped lay the foundation for 20th century crinoid taxonomy (Bather, 1890a, 1890b, 1891, 1898, 1898-1899, 1899, 1900a, 1900b; Wachsmuth and Springer, 1891, 1897; Springer, 1900). Bather's (1898-1899) six-part review of Wachsmuth and Springer's (1897) The North American Crinoidea Camerata was hypercritical, and he used it as a means to promote his own ideas on morphology and classification.

Their critiques were strident as they referred to each other's ideas as "faulty" or "ridiculous" (Wachsmuth and Springer, 1891; Bather, 1891). Bather claimed that the accusations of "my very friendly antagonists" would "damage my scientific reputation" and that they were "learned rather than lucid writers." Bather (1898-1899, p. 526) even went so far as to state that Wachsmuth and Springer (1897) had told one of their illustrators to put in structures the illustrator "really had a difficulty in seeing." This led Springer (1900) to vigorously protest Bather's "accusation of misrepresentation of facts." Bather (1900b) subsequently apologized for this remark but stated that his "oft-repeated criticism of the assertions of Wachsmuth and Springer" caused "a definite advance in science." These exchanges were 
TABLE 1-Early classifications of the Crinoidea.

\begin{tabular}{lcc}
\hline \hline Wachsmuth and Springer $(1891,1897)$ & Bather (1899) & Moore and Laudon (1943) \\
\hline Class CRINOIDEA & Class CRINOIDEA & Class CRINOIDEA \\
Order INADUNATA & Subclass MONOCYCLICA & Subclass INADUNATA \\
Suborder LARVIFORMIA & Order INADUNATA & Order DISPARATA \\
Suborder FISTULATA & Order ADUNATA & Order CLADOIDEA \\
Order CAMERATA & Order CAMERATA & Subclass FLEXIBILIA \\
Order ARTICULATA & Order TAXOCRINOIDEA \\
Suborder IMPINNATA & Order INADCLICA & Order SAGENOCRINOIDEA \\
Suborder PINNATA & Order FLEXIBILIA & Subclass CAMERATA \\
& Grade IMPINNATA & Order DIPLOBATHRA \\
& Orade PINNATA & Order MONOBATHRA \\
\hline
\end{tabular}

not of the caliber of the Marsh-Cope rivalry in paleontology, but the degree of acrimony is remarkable nonetheless.

The details of their arguments usually concerned the morphology of the anal and tegminal plates in the Fistulata and the phylogenetic significance of inferred homologies among these plates. But their arguments extended to higher level classification with Bather (1898) suggesting that Wachsmuth and Springer's (1897) crinoid classification was "a key to structure rather than an epitome of genetic affinity." Ultimately such harsh exchanges probably did help advance the field, as Bather (1900b) asserted.

Bather's (1890b, 1893, 1898) focus on analysis of the Fistulata of Wachsmuth and Springer, (1885; see Springer, 1913) led him to infer that the Larviformia (disparids mostly, lacking an anal sac or tube) and Fistulata (Table 1) were evolutionary grades, a viewpoint never accepted by Springer (Bassler and Moodey, 1943). Subsequently, Bather (1899) created the Monocyclica Inadunata (disparids mostly) and the Dicyclica Inadunata, which was further divided into the Cyathocrinoidea (Cyathocrinina) and the Dendrocrinoidea (Dendrocrinina and Poteriocrinina), divisions later retained by Moore and Laudon (1943) and revised in Moore et al. (1978) (Table 1). Bather (1890b, 1893) had previously accepted Wachsmuth and Springer's (1885) Inadunata, but later took the very unusual step of creating two crinoid subclasses on the basis of the number of plate circlets below the radials, thus the Monocyclica and Dicyclica (Bather, 1899), where monocyclic crinoids have one circlet beneath the radial plates and dicyclic crinoids have two. He believed these two groupings to be monophyletic as he could not bridge the evolutionary gap between their cup types. Peculiarly, both subclasses included the orders Inadunata and Camerata, which he recognized were polyphyletic, but he retained them stating it is "well to accept existing terms so far as possible." Wachsmuth and Springer (1897) had not separated camerates on the basis of plate circlets, but Bather's (1899) Monocyclica Camerata and Dicyclica Camerata anticipated Moore and Laudon's (1943) Monobathra and Diplobathra. Bather (1899) also created the Monocyclica Adunata for camerates lacking fixed brachials in the cup. The one area of agreement was that both sides grouped the flexibles and articulates together with each recognizing the Impinnata (flexibles) and the Pinnata (articulates) in the Flexibilia (Bather, 1899) or Articulata (Wachsmuth and Springer, 1897). Springer (1920) later accepted the term Flexibilia, but there is little evidence he accepted Bather's higher-level taxonomy as indicated in Bassler and Moodey (1943), who basically followed Springer's ideas on higher-level classification. The Bather-Wachsmuth and Springer exchanges brought attention to major taxonomic divisions that only later were recognized in Moore and Laudon (1943) and Moore and Teichert (1978), although it took these later studies to sort it all out (see below).

Jaekel (1918) published an extensive classification introducing several new subclasses, orders and suborders, few of which were incorporated in later classifications, these being the suborders Hybocrinina and Poteriocrinina in Moore and Teichert (1978). He recognized three subclasses: Eocrinoidea (now their own class), Cladocrinoidea (basically camerates), and Pentacrinoidea (disparids, cladids, flexibles, and articulates). Jaekel's efforts apparently had little impact on later classification schemes (Lane, 1978).

Between 1900 and 1925, study of modern crinoids was largely confined to descriptive studies and dominated by the results of oceanographic expeditions, such as, among others, the voyages of the Albatross (A. H. Clark, 1908, 1911) and the Endeavor (H. L. Clark, 1916), the Siboga Expedition (Döderlein, 1907), and Bock's Expedition (Gislén, 1922). These systematic treatments expanded both the taxonomic diversity of living crinoids as well as expanding the documented geographic distribution of living crinoids. Systematic work on living crinoids culminated during this period with the beginning of the publication of A. H. Clark's Monograph on the Existing Crinoidea (Clark, 1915, 1931), although publication of the parts of this significant contribution was not completed until 1967 (Clark and Clark, 1967).

Similarly, systematic work dominated post-Paleozoic fossil crinoid studies during this interval, but, as mentioned above, agreement did not exist on the phylogenetic and systematic relationships between Paleozoic and post-Paleozoic crinoids. The orders Comatulida and Uintacrinida were defined by A. H. Clark (1908) and Broili (1921), respectively; and division of the comatulids into currently used superfamilies was completed by 1925 , with the exception of the superfamily Paracomatulacea (Hess, 1951).

\section{CRINOID STUDIES 1926 TO 1943}

Several workers, including Goldring, Schmidt, Wright, Kirk, Laudon, Moore, and Wanner, made significant contributions to the study of fossil crinoids during this period. Winifred Goldring became the first woman State Paleontologist of New York in 1934 and later the first woman president of the Paleontological Society in 1949. She wrote extensively on Devonian crinoids from 1923 to 1951, with her first publication the massive Devonian Crinoids of the State of New York (1923). Her body of work is still important to students of Devonian crinoids. W. Erich Schmidt (1934, 1942, and others) wrote from 1906 to 1952, mostly on European Devonian crinoids. James Wright wrote numerous papers from 1911-1960 on British and Irish Carboniferous crinoids. His first major monograph The Scottish Carboniferous Crinoidea (1939) appeared just before WWII. After the war the synthesis of his life's work, A Monograph of the British Carboniferous Crinoidea, was published in 10 installments (Wright, 1950-1960). Wright's body of work is still an authoritative source on British Carboniferous crinoids. Edwin Kirk produced a substantial body of work from 1929 to 1948, mostly on Carboniferous cladids (e.g., Kirk, 1938). Lowell Laudon is best known for his work on Kinderhookian crinoids (e.g., Laudon and Beane, 1937). Raymond C. Moore began an extensive study of upper Paleozoic crinoids (e.g., Moore and Plummer, 1940). Johannes Wanner wrote extensively on Permian crinoids from Timor (e.g., Wanner, 1931).

In 1943 Moore and Laudon's Evolution and Classification of 


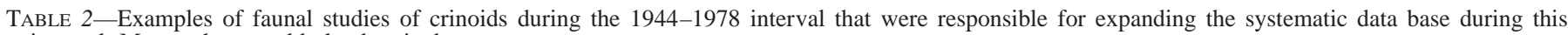
interval. Many others could also be cited.

\begin{tabular}{|c|c|c|}
\hline Time & North America & Europe, Australia, Timor \\
\hline Cenozoic & Oregon (Moore \& Vokes, 1953) & Europe (Rasmussen, 1972) \\
\hline \multirow[t]{3}{*}{ Cretaceous } & Mississippi (Moore, 1967) & Bohemia (Nekvasilova \& Prokop, 1963) \\
\hline & Texas (Peck, 1943; Peck \& Watkins, 1972) & England (Peck, 1955) \\
\hline & & Europe (Rasmussen, 1961, and others) \\
\hline \multirow[t]{2}{*}{ Jurassic } & Wyoming (Koch, 1962) & Switzerland (Hess, 1972, and others) \\
\hline & & Europe (Sieverts-Doreck, 1951, and others) \\
\hline Triassic & Mexico (Peck, 1948) & Poland (Lefeld, 1958) \\
\hline Permian & Nevada (Lane \& Webster, 1966) & Australia (Teichert, 1949; Willink, 1978) \\
\hline \multirow[t]{3}{*}{$\begin{array}{l}\text { Pennsylvanian (Upper Car- } \\
\text { boniferous) }\end{array}$} & $\begin{array}{l}\text { Appalachian Basin (Burke, 1968, 1973, and } \\
\text { others) }\end{array}$ & $\begin{array}{l}\text { Timor (Wanner, 1949, and others) } \\
\text { United Kingdom (Wright, } 1950 \text { to 1960) }\end{array}$ \\
\hline & $\begin{array}{l}\text { Arkansas, Oklahoma, and Texas, (Moore \& } \\
\text { Strimple, } 1973 \text { and others) }\end{array}$ & \\
\hline & Illinois (Strimple \& Moore, 1971) & \\
\hline \multirow{3}{*}{$\begin{array}{l}\text { Mississippian (Lower Car- } \\
\text { boniferous) }\end{array}$} & Alberta (Laudon et al., 1952) & \\
\hline & Indiana (Van Sant \& Lane, 1964) & \\
\hline & Mississippi River Valley (Laudon, 1973) & \\
\hline Devonian & $\begin{array}{l}\text { Ohio (Kesling \& Mintz, 1963; Kesling, 1965, } \\
\text { and others) }\end{array}$ & $\begin{array}{l}\text { Czech Republic (Prokop, } 1970 \text { and others) } \\
\text { Spain (Breimer, 1962) }\end{array}$ \\
\hline Silurian & Oklahoma (Strimple, 1963) & Sweden (Ubaghs, 1956, and others) \\
\hline \multirow{4}{*}{$\begin{array}{l}\text { Upper and Middle Ordovi- } \\
\text { cian }\end{array}$} & Illinois and Wisconsin (Kolata, 1975) & United Kingdom (Ramsbottom, 1961) \\
\hline & Minnesota (Brower \& Veinus, 1978) & \\
\hline & $\begin{array}{l}\text { Missouri (Brower, 1973; Strimple \& Watkins, } \\
\text { 1955) }\end{array}$ & \\
\hline & $\begin{array}{l}\text { Tennessee and Virginia (Brower \& Veinus, } \\
\text { 1974) }\end{array}$ & \\
\hline \multirow[t]{2}{*}{ Early Ordovician } & California (Strimple \& McGinnis, 1972) & France (Ubaghs, 1969, 1972) \\
\hline & Utah (Lane, 1970) & United Kingdom (Bates, 1968) \\
\hline
\end{tabular}

Paleozoic Crinoids was published. This seminal work was greatly influenced by Wachsmuth and Springer's and Bather's ideas on classification. Moore and Laudon's classification of Paleozoic crinoids encompassed three subclasses, including the Inadunata and Camerata of Wachsmuth and Springer (1885) and Zittel's (1895) Flexibilia (Table 1). Bather's emphasis on monocyclic and dicyclic cups led to Moore and Laudon's Disparata and Cladoidea within the Inadunata, and their Monobathra and Diplobathra within the Camerata. Moore and Laudon also incorporated Bather's (1899) Cyathocrinoidea and Dendrocrinoidea as the two primary divisions of their Cladoidea. Thus, Wachsmuth and Springer's ideas regarding subclasses prevailed, whereas Bather's ideas regarding orders and suborders prevailed. Moore and Laudon created the Disparata, Cladoidea, Monobathra, and Diplobathra because of the obvious unacceptability of Bather's (1899) Monocyclica Inadunata, Dicyclica Inadunata, Monocyclica Camerata, and Dicyclica Camerata, respectively. They also placed Bather's (1899) Monocyclica Adunata in the Monobathra because these crinoids with superficially simple calyces were a polyphyletic grouping with origins among different monocyclic camerates. Prior to Moore and Laudon (1943), North American workers had followed Wachsmuth and Springer's (1897) classification, whereas European workers had followed Bather (1899, 1900a).

Another key publication in 1943 was Bassler and Moodey's (1943) Bibliographic and Faunal Index of Paleozoic Pelmatozoan Echinoderms. This was based on Springer's card files that still remain in the Smithsonian. This card file was completed, with the help of Springer's daughter Ada, through 1915, with updates by Moodey (Bassler and Moodey, 1943, p. 1). This comprehensive compilation of literature and faunal lists greatly helped to facilitate a rapid increase in crinoid studies following WWII.

Study of post-Paleozoic crinoids continued with further monographs by A. H. Clark, plus numerous systematic studies. Key during this period was the publication of Fossilium Catalogous volumes on post-Paleozoic crinoids (Biese, 1934, 1935-1937; Biese and Sieverts-Doreck, 1937, 1939a, 1939b; Sieverts-Doreck and Biese, 1939).

\section{CRINOID STUDIES 1944 TO 1978}

1944-1978 systematic studies.-1943 marked the close of the influence of Frank Springer, but it began the dominant influence of Raymond C. Moore on the study of the Crinoidea. In North America, Moore, his students, and his colleagues made substantial strides describing new Paleozoic faunas and beginning paleobiologic studies of crinoids, ultimately leading to publication of the crinoid Treatise on Invertebrate Paleontology (Moore and Teichert, 1978).

In Europe, two Treatises were also published during this interval: Treaté de Paléontologie, Tome III (Ubaghs, 1953) and Klass Crinoidea. Morskie lilii. Sistematicheskaia chasti (Class Crinoidea. Crinoids. Systematic part) (Arendt and Hecker, 1964). Both were important syntheses, but Ubaghs (1953) had a broader, more significant impact, both in itself and because it was a basis from which Ubaghs prepared major portions of the Treatise (Moore and Teichert, 1978).

During this interval, which included both the post-World War II revitalization of academic science and the expansion of North American colleges and universities to accommodate the "babyboom" generation, an increase in studies significantly broadened the crinoid data base, both through refinement of known faunas and by discovery of new faunas (especially in North America and Europe). A comprehensive listing is not possible, but examples are cited in Table 2. Most significant among these were description of Early and Middle Ordovician faunas that began to shape the understanding of the initial two radiations of crinoids. The "Age of Crinoids," the Mississippian, received considerable study in North America, the United Kingdom, and Ireland. Knowledge of Pennsylvanian and Permian crinoids, previously known from relatively few faunas and largely from poorly preserved material, was expanded considerably.

Independent classifications of crinoid columnals and pluricolumnals were proposed by Stukalina (1966) and Moore and Miller (1968), and this approach was developed extensively by several additional workers. A principal aim in columnal and pluricolumnal studies has been to develop a means by which to capitalize 
TABLE 3-Crinoid classification by Moore and Teichert (1978).

\begin{tabular}{l}
\hline \hline Class CRINOIDEA Miller, 1821 \\
Subclass ECHMATOCRINEA Sprinkle and Moore, 1978 \\
Order ECHMATOCRINIDA Sprinkle and Moore, 1978 \\
Subclass CAMERATA Wachsmuth and Springer, 1885 \\
Order DIPLOBATHRIDA Moore and Laudon, 1943 \\
Order MONOBATHRIDA Moore and Laudon, 1943 \\
Subclass INADUNATA Wachsmuth and Springer, 1885 \\
Order DISPARIDA Moore and Laudon, 1943 \\
Order HYBOCRINIDA Jaekel, 1918 \\
Order CORONATA Jaekel, 1918 \\
Order CLADIDA Moore and Laudon, 1943 \\
Subclass FLEXIBILIA Zittel, 1895 \\
Order TAXOCRINIDA Springer, 1913 \\
Order SAGENOCRINIDA Springer, 1913 \\
Subclass ARTICULATA Zittel, 1879 \\
Order MILLERICRINIDA Sieverts-Doreck, 1952 \\
Order CYRTOCRINIDA Sieverts-Doreck, 1952 \\
Order BOURGUETICRINIDA Sieverts-Doreck, 1952 \\
Order ISOCRINIDA Sieverts-Doreck, 1952 \\
Order COMATULIDA A. H. Clark, 1908 \\
Order UINTACRINIDA Broili, 1921 \\
Order ROVEACRINIDA Sieverts-Doreck, 1952 \\
*Class HEMISTREPTOCRINOIDEA Arendt, 1976 \\
Order HEMISTREPTOCRINIDA Arendt, 1976 \\
\hline
\end{tabular}

* New Class of Crinoidea proposed by Arendt (1976).

on the abundance of columnal fragments for biostratigraphic purposes. Although, it has had some success, it also has yielded a sometimes confusing parataxonomy for crinoids. A later exception discussed below was the Ordovician-Silurian boundary study by Donovan (1986, 1989, 1994).

Post-Paleozoic crinoid systematics were stabilized by the works of Sieverts-Doreck $(1952,1953)$. Of the seven orders recognized in Rasmussen (1978), only two had been recognized prior to 1950 (see Table 3). Sieverts-Doreck $(1952,1953)$ named the orders Millericrinida, Cyrtocrinida, Bourgueticrinida, Isocrinida, and Roveacrinida (Table 3). These seminal studies established the Articulata subdivisions into orders that have since remained in place with only the recent addition of the Encrinida (Hagdorn, 1988) and the Ampelocrinida for stem articulates (Webster and Jell, 1999) (see below).

With the exception of Rasmussen, Peck, and Hess, relatively little work was completed on post-Paleozoic fossil crinoids during this interval (Table 2), however this time witnessed the completion of systematic studies of living crinoids by A. H. Clark and T. Gislén, and A. M. Clark.

The systematic treatment of the Articulata in the Treatise was a much needed complete compilation, as discussed in Rasmussen (1978, p. T813). Rasmussen (1978) brought together largely the work of H. Sieverts-Doreck, A. H. Clark, and his own (in addition to contributions by H. A. Lowenstam and R. E. Peck). This synthesis added only a few new suprageneric categories, and this comprehensive consideration was invaluable.

The work by systematists on Paleozoic crinoids was significantly advanced by the Bibliography and Index of Paleozoic Crinoids by Webster (1973, 1977). These and subsequent compilations are a continuation of Bassler and Moodey (1943) and provide ready access to both the history of names and the history of taxonomic concepts for Paleozoic crinoids.

1944 to 1978 paleobiology. - The beginnings of modern ecologic and paleobiologic studies occurred during this interval. However, relatively little of this work was incorporated into the Treatise, and certainly, the impact of this early work for paleobiologic and paleoecologic studies for the remainder of the century was not anticipated in the Treatise.

Pioneering ecologic work was completed on both unstalked and stalked crinoids through in vivo observation and study. Unstalked crinoids were studied in the Red Sea (Magnus, 1963, 1967; Rutman and Fishelson, 1969) and in the Caribbean Sea (Meyer, 1973a, 1973b; Macurda, 1973). Scientific study from submersibles opened access to deep sea, stalked crinoids, with studies largely in the depths of the Caribbean Sea (Macurda and Meyer, 1974, 1976). These ecologic studies significantly changed our understanding of crinoids - crinoids should not be viewed as rheophobic (current avoiding) but as rheophilic (current seeking) organisms. Crinoids rely on ambient currents for feeding, and they actively orient their arms into a filtration fan when currents are present. Shallow-water unstalked crinoids most commonly develop planar filtration fans when exposed to unidirectional currents, and deep-water stalked isocrinids position their arms into a parabolic fan. When currents are slack, feeding is much reduced or absent.

Actualistic taphonomy studies were also initiated during this interval (Blyth Cain, 1968; Meyer, 1971; Liddell, 1975). These and later studies provided an explanation as to why complete crinoid fossils are relatively rare, i.e., a dead, unstalked crinoid lying on the sea floor completely disarticulated into isolated ossicles in only a few days. Thus, very rapid burial is required for complete preservation of fossil crinoids. Crinoid lagerstätten are now known to be obrution deposits, the result of rapid burial of live crinoids.

These early ecologic and taphonomic studies were quickly adapted to the interpretation of fossil crinoids, resulting in a number of pioneering paleobiologic studies. Important examples among these are the paleoecology of stalked crinoids (Lane, 1963, 1973), paleoecology of epiplanktonic crinoids (Seilacher et al., 1968), paleocommunity analysis (Lane, 1972, 1973), taphonomic studies (Lane, 1973), and biometric studies and ontogeny (Brower, 1973, 1974). Innovative paleobiologic studies by Haugh (1973, 1975a, 1975b) used chertified molds and casts of crinoid to reconstruct the details of soft-part, internal anatomy of Lower Mississippian camerates.

Application of scanning electron microscopy to paleontology opened a new field of inquiry on the morphology of crinoid articular facets. The work of Macurda and Meyer (1975, 1981) delineated microstructure patterns on facets; however, few studies have attempted to carry this work further and to apply it to paleobiologic questions because of the apparent paucity of unaltered stereom.

The 1978 Treatise.-The Treatise (Moore and Teichert, 1978) was an extraordinary compilation that consolidated what was known about crinoids and forced decisions on issues less well known. Like any treatise that comprehensively summarizes a topic, publication immediately exposed gaps in knowledge and established an agenda for continued work. Some of the problems could only be recognized in the context of this new comprehensive treatment. Some problems were created by the mere act of compilation, such as in the following anecdote related by H. L. Strimple. After being enthusiastically criticized by a colleague about the familial placement of a specific genus in the Treatise, Strimple was reported to have replied "We had to put it somewhere!” (personal commun., A. S. Horowitz, 1978).

The basic classification of Moore and Laudon (1943) was adopted in the Treatise (Moore and Teichert, 1978), with all but one of the post-Paleozoic crinoids placed in the subclass Articulata, addition of the Cambrian subclass Echmatocrinea, elevation of the hybocrinids and coronoids to orders within the Inadunata, and mention of the hemistreptocrinids (Table 3). Thus, Frank Springer and Francis Bather continued to influence thinking on the Crinoidea. As argued by Ausich (1998a, 1998c), the structure of this classification was based largely on knowledge of the morphology of Silurian to Mississippian crinoids. Thus, the phylogenetic relationships of this classification were derived largely by 
TABLE 4-Crinoid classification by Simms and Sevastopulo (1993).

\begin{tabular}{l}
\hline \hline Class CRINOIDEA \\
Subclass CAMERATA \\
Order DIPLOBATHRIDA \\
Order MONOBATHRIDA \\
Subclass DISPARIDA \\
Subclass CLADIDA \\
"STEM-GROUP CLADIDS", \\
Infraclass CYATHOCRININA \\
Infraclass FLEXIBILIA \\
Infraclass ARTICULATA \\
Incertae Sedis ('Subclass') HYBOCRINIDA \\
\hline
\end{tabular}

inferring lineages from these middle Paleozoic crinoids back into the lower Paleozoic.

\section{CRINOID STUDIES 1979 TO 2001}

Crinoid systematic study since 1978.-The Treatise classification left those expecting a phylogenetic classification puzzled in many instances. Four examples illustrate this point. First, two diplobathrid camerate genera (one Ordovician and one Devonian) were grouped into the suborder Zygodiplobathrida, separate from all other diplobathrids. These two crinoids share an unusual calyx construction with radial and basal plates in a single circlet, but does this make sense phylogenetically? Second, all post-Paleozoic crinoids were placed in the Articulata, except Encrinus (Middle Triassic), which was placed in the Cladida. What was the origin and early evolution of the Articulata with this sort of temporal classification? The third and fourth issues concern the integrity of the Inadunata (sensu Moore and Teichert, 1978). Third, the monophyly of the Inadunata was questioned by Kelly (1982, 1986), Donovan (1988), Sevastopulo and Lane (1988), Simms and Sevastopulo (1993), and Simms (1994), who regarded the cladids as not closely related to the disparids. Ultimately, Simms and Sevastopulo (1993) eliminated the Inadunata and elevated the Cladida and Disparida to subclass level. Fourth, higher-level taxa within the Cladida lacked diagnostic definitions, which raised serious questions about the monophyly of cladid suborders (McIntosh, 1979, 1986; Kammer and Ausich, 1992), particularly the placement of all pinnulate cladids in the Poteriocrinina, which may have been derived from different lineages in the Dendrocrinina. Further work is needed on this problem.

Simms and Sevastopulo (1993) concluded that the Articulata was monophyletic and that the Disparida and Cladida were subclasses based on a strict monophyletic analysis. These decisions are uniformly accepted. However, other results from this strict monophyletic approach have been questioned. Rather than including the Flexibilia and Articulata in the Cladida, Ausich (1998a, 1998c) (Tables 4 and 5) recognized these all as subclass in rank. Also, Simms and Sevastopulo (1993) recognized "stemgroup articulates" among Paleozoic cladids, whereas Webster and Jell (1999) recognized these advanced forms as articulates. Simms and Sevastopulo (1993) defined the Articulata on the basis of three characters: 1 , dicyclic or cryptodicyclic aboral cup; 2 , no anal plates in the aboral cup; and 3, the entoneural system enclosed within brachials and radial plates. Thus, articulates are monophyletic and post-Paleozoic. Alternatively, Webster and Jell (1999) did not regard the absence of anal plates in the aboral cup to be a synapomorphy for the Articulata. They defined the Articulata as crinoids with "brachial pairs with alternating muscular and cryptosyzygial articulations." In this view Paleozoic crinoids as old as Corythocrinus Kirk (late Osagean, Tournaisian) are articulates and are assigned to the articulate order Ampelocrinida (Webster and Jell, 1999) (Table 6). These primitive articulates are characterized by the following: 1) dicyclic or cryptodicylic aboral cup; 2) one to three anal plates in the aboral cup; 3) entoneural
TABLE 5-Crinoid subclass classification in Ausich (1998c).

\begin{tabular}{l}
\hline \hline Class CRINOIDEA \\
Subclass AETHOCRINEA \\
Subclass CLADIDA \\
Subclass CAMERATA \\
Subclass FLEXIBILIA \\
Subclass ARTICULATA \\
Subclass DISPARIDA \\
\hline
\end{tabular}

system enclosed within brachials and radial plates; 4) first arm division on the second to fourth primibrachial; 5) cuneate uniserial arms; 6) syzygial brachial pairs with muscular articulations alternating with a cryptosyzgial ligamentary articulation; 7) pinnulate arms; 8) brachial articular facets with well-defined muscular and ligamentary fossae; and 9) cirri with multiradiate articular facets distally and articular facets with a transverse ridge throughout (Webster and Jell, 1999). Webster and Jell's hypothesis regarding the recognition of Paleozoic articulates from among the cladids has yet to be evaluated by other crinoid workers.

This addition to the orders of the Articulata (sensu Rasmussen, 1978) was added to a previous one by Hagdorn (1988). Hagdorn (1988) elevated Encrinacea Matsumoto (1929) to the Order Encrinida.

Important taxa removed from the Crinoidea since 1978 include the coronate echinoderms (Brett et al., 1983); the Hemistreptocrinoidea (Arendt and Rozhnov, 1995), and Echmatocrinus (Conway Morris, 1993; Simms et al., 1993; and Ausich and Babcock, 1998, 2000; but see Sprinkle and Collins, 1998).

Crinoid classification and phylogeny is based on an understanding of the basic homologies of aboral cup plates among the Crinoidea, and even this basic tenet was brought under discussion during the last decade. Simms (1994) concluded that plate homologies between the two basic types of aboral cup construction, monocyclic and dicyclic, were not always as had traditionally been assumed. Alternatively, Ausich (1996) countered the arguments of Simms (1994) and proposed other deviations from the strict homologies of Moore and Teichert (1978). Ausich (1996) proposed that the most primitive crinoid had a four-circlet (tricyclic) aboral cup composed of, from top to bottom, radials, basals, infrabasals, and lintels (three circlets beneath the radials). In the Ausich (1996) scheme, only disparids depart from Moore and Teichert (1978) homologies, by having a calyx constructed of either radials, infrabasals, and lintels or only infrabasals and lintels.

The Crinoidea as a whole is regarded as monophyletic, but from whence this clade was derived and where it fits within the Echinodermata are matters of debate. A multiple, irregular plated ancestor has been the traditional expectation for the crinoid ancestor, and Echmatocrinus seemed like a possible ancestor for nearly two decades (Sprinkle and Moore, 1978; Ubaghs, 1978). However, the affinities of Echmatocrinus were questioned by several authors (Conway Morris, 1993; Signor and Vermeij, 1994;

TABLE 6-Classification of the suborder Articulata from Webster and Jell (1999).

\footnotetext{
Subclass ARTICULATA Zittel, 1879

Order AMPELOCRINIDA Webster and Jell, 1999

Order ENCRINIDA Matsumoto, 1929

Order MILLERICRINIDA Sieverts-Doreck, 1952

Order CYRTOCRINIDA Sievents-Doreck, 1952

Order BOURGUETICRINIDA Sieverts-Dork, 1952

Order ISOCRINIDA Sieverts-Doreck, 1952

Order COMATULIDA A.H. Clark, 1908

Order UINTACRINIDA Broili, 1921

Order ROVEACRINIDA Sieverts-Doreck, 1952
} 
Donovan, 1995), and in 1998 Ausich and Babcock (see also Ausich and Babcock, 2000) concluded that Echmatocrinus was an octocoral. Reconsideration of crinoid origins where Echmatocrinus is not an echinoderm led Ausich (1998a, 1998b, 1999) to conclude that crinoids were derived from primitive rhombiferans and that the first crinoids had tricyclic aboral cups. The notion that crinoids evolved from Echmatocrinus is maintained by Sprinkle and Guensburg (1997), Guensburg and Sprinkle (1997, 1998), and Sprinkle and Collins (1998); and they have also argued that the multiple, irregular plated ancestor was ultimately derived from edrioasteroids (Guensburg and Sprinkle, 1997, 2001). Ultimately, the interpretation of important, new Early Ordovician echinoderms (Guensburg and Sprinkle, 2001) may lead to a better understanding of the crinoid clade origins. Also, this new material may help resolve echinoderm plylogenetic questions raised by David et al. (2000), who place the stylophorans as a sister group of crownward crinoids.

Systematic studies have largely been faunistic in nature, with the exception of the revision of the Dichocrinidae (Broadhead, 1981). Significant systematic contributions from this interval include thorough systematic revisions of entire faunas and description of new faunas either in new geographic areas or in critical stratigraphic intervals. Revisions of faunas at critical intervals, such as the late Osagean-early Meramecian of the midcontinental United States (Ausich and Kammer, 1990; Kammer and Ausich, 1992; and others), is prerequisite to evolutionary paleoecologic studies (Ausich et al., 1994; Kammer et al., 1997, 1998). Key stratigraphic intervals where important new faunas filled gaps in the understanding of crinoids includes the Early Ordovician, Early Silurian, and Permian (Table 7). Especially significant new findings among Permian crinoids is that the majority of crinoids from Timor are actually Early Permian rather than Late Permian, thus moving the principal biotic crisis for crinoids from the end-Permian to the end-Early Permian (Webster, 1990; Webster and Jell, 1992).

Descriptive studies of faunas from new geographic regions are key as evolutionary paleoecologic questions become more global in scope. Examples of this "frontier crinoid paleontology" include the Devonian of China (Lane et al., 1997), Mississippian of China (Chen and Yao, 1993), Permian of Australia (Willink, 1979; Webster and Jell, 1992, 1999), Permian of Thailand (Webster and Jell, 1993), Eocene of Antarctica (Meyer and Oji, 1993; Baumiller and Gaździcki, 1996), and living, deep-water faunas from New Caledonia (Roux, 1994) (see Table 7).

Lane and Sevastopulo (1982) and Sevastopulo and Lane (1988) are examples of a series of studies on Paleozoic microcrinoids. These are adult, undoubtedly paedomorphic, crinoids with an aboral cup height generally less than one millimeter. This work has resulted in a more robust taxonomy of these very small crinoids, and more important, it has led to a more complete understanding of early ontogeny, especially among disparids.

Substantial systematic revisions among living crinoids were few, with the exception of the comasterids. Rowe et al. (1986) revised the comasterids (Order Comatulida) by recognizing the type and arrangement of pinnule combs as key diagnostic features for genera, thus differing from Clark (1931).

The Webster (1986, 1988, 1993) Bibliography and Index of Paleozoic Crinoids continued to be published and a comprehensive volume that includes the entire history of Paleozoic crinoid study is anticipated. These nomenclatoral works have incalculable value for furthering the study of Paleozoic crinoids. Publication of Fossil Crinoids (Hess et al., 1999) should also promote future study of crinoids, generating both interest and understanding in this the most diverse and abundant group of pelmatozoan echinoderms.
1979 to 1999 paleobiology.-Ecologic and paleoecologic studies of crinoids flourished during the final quarter of the twentieth century. A very productive synergism developed among crinoid biologists, crinoid paleontologists, and those who worked in both fields. Some of the more important ecologic and biologic findings include 1) feeding mechanisms of crinoids (Meyer, 1979; Baumiller and Woodley, 1991); 2) ecology of living crinoids (Meyer and Macurda, 1980; Messing et al., 1990); 3) stalked crinoids can detach their holdfasts and move to more favorable sites (Messing et al., 1988); 4) a crownless crinoid may remain erect and alive for more than one year (Conan et al., 1981; Fujita et al., 1987; Messing et al., 1988; and Oji and Amemiya, 1998); 5) even pluricolumnal segments on the sea floor may remain alive for a long period of time (Oji and Amemiya, 1998); 6) delineation of connective tissue types among living crinoids (Holland and Grimmer, 1981; Grimmer et al., 1985; and others); and 7) regeneration capabilities of crinoids (Amemiya and Oji, 1992; Candia Carnevalli et al., 1993; and others).

Parallel to these are the following important paleoecologic/paleobiologic advances: 1) niche differentiation, feeding mechanisms, and community structure in fossil faunas (Ausich, 1980; Ausich and Bottjer, 1982; Kammer, 1985), which delineated the paleoecologic structure of the majority of benthic crinoids; 2) reexamination of the paleoecology of unusual fossil crinoids, such as uintacrinids (Milsom et al., 1994; Meyer et al., 1999), marsupiocrinds and antedonids (Milsom, 1994; Milsom et al., 1994), calceocrinids (Ausich, 1986a), myelodactylids (Donovan and Franzén-Bengtson, 1988), pseudoplanktonic crinoids (Haude, 1980; Simms, 1986; Hess et al., 1999), among others; 3) differentiation of crinoid paleocommunities (Ausich et al., 1979; Brett, 1985; Kammer and Ausich, 1987; Chesnut and Ettensohn, 1988; Holterhoff, 1996).

Early actualist taphonomic studies were developed further both for shallow- and deep-water crinoids (Meyer and Meyer, 1986; Lewis et al., 1990; Baumiller et al., 1995). These studies were applied in many ways to establish preservational constraints and to expand extractable information from the fossil record: 1) to delineate burial conditions for complete crinoid preservation and to recognize that tempestites are one of the most common agents of crinoid preservation (Lewis, 1980; Taylor and Brett, 1996; and many others); 2) definition of preservational expectations among major clades and taphonomic facies that follow (Meyer et al., 1989; Ausich and Sevastopulo, 1994); 3) delineation of crinoid deposit types (Ausich, 1997; Brett et al., 1997); and 4) determination of soft-tissue types and characteristics in Mesozoic and Paleozoic crinoids (Baumiller and Ausich, 1992; Ausich and Baumiller, 1993; and others).

Macroevolutionary advances include 1) those delineating the morphological disparity of crinoids through the Phanerozoic (Foote, 1995, 2000); 2) recognition of three macroevolutionary faunas during the Paleozoic (Baumiller, 1993; Ausich et al., 1994); 3) consideration of the patterns and processes bounding these faunas, such as the origin of crinoids (Ausich, 1998a, 1998b, 1998c, 1999; Sprinkle and Collins, 1998), the Early Ordovician radiation of epifaunal suspension feeders (Guensburg and Sprinkle, 1992), the end-Ordovician extinction and Early Silurian recovery of crinoids (Eckert, 1988; Donovan, 1988, 1989, 1994), the end-Osagean rapid faunal turnover (Ausich et al., 1994; Kammer et al., 1997, 1998), and 4) the demise of shallow-water stalked crinoids (Meyer and Macurda, 1977).

\section{CHALLENGES FOR THE TWENTY-FIRST CENTURY}

The close of the 20th century saw a decline in the rate of crinoid publications, which reflects retirements among the postWWII generation of academic paleontologists rather than a diminishing interest in crinoid paleontology. Many significant ques- 


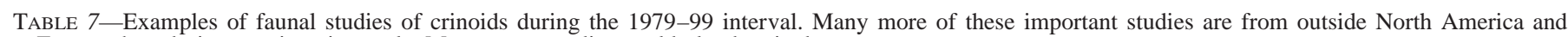
Europe than during previous intervals. Many more studies could also be cited.

\begin{tabular}{|c|c|c|c|}
\hline Time & North America & Europe & Elsewhere \\
\hline Modern & & & $\begin{array}{l}\text { Indonesia (Améziane, 1997) } \\
\text { Philippines (Bourseau \& Roux, 1989) } \\
\text { Japan (Fujita, et al., 1987) } \\
\text { New Caledonia (Roux, 1994) } \\
\text { Spain (Roux, 1977; Conan et al., 1981) }\end{array}$ \\
\hline Cenozoic & & $\begin{array}{l}\text { Belgium and Netherlands (Jagt, 1995, } \\
\text { 1999) }\end{array}$ & $\begin{array}{l}\text { Antarctica (Meyer \& Oji, 1993; Baumill- } \\
\quad \text { er \& Gaździcki, 1996) }\end{array}$ \\
\hline Cretaceous & & $\begin{array}{l}\text { Czech Republic (Zitt, 1979, 1980, and oth- } \\
\text { ers) } \\
\text { Crimea (Klikushin, 1987) }\end{array}$ & Japan (Oji, 1985) \\
\hline Jurassic & & $\begin{array}{l}\text { Crimea (Klikushin, 1996) } \\
\text { Europe (Sieverts-Doreck, 1981, and others) } \\
\text { France (Manni et al., 1985) } \\
\text { Poland (Pisera \& Dzik, 1979) } \\
\text { Switzerland (Hess, 1983, and others) } \\
\text { Turkey (Nicosia, 1991) } \\
\text { United Kingdom (Simms, 1989) }\end{array}$ & \\
\hline Triassic & & $\begin{array}{l}\text { Austria, Turkey, Indonesia (Kristan-Toll- } \\
\text { man, 1990) } \\
\text { Germany (Hagdorn, 1993) } \\
\text { Worldwide (Hagdorn, 1995) }\end{array}$ & \\
\hline Permian & & & $\begin{array}{l}\text { Australia (Webster, 1990; Willink; 1979, } \\
\quad \text { and others; Webster and Jell, 1992) } \\
\text { Oman (Jell \& Willink, 1993) } \\
\text { Thailand (Webster \& Jell, 1993) } \\
\text { Tunisia (Lane, 1979) }\end{array}$ \\
\hline $\begin{array}{l}\text { Pennsylvanian } \\
\text { (Upper Carbon- } \\
\text { iferous) }\end{array}$ & $\begin{array}{l}\text { Nebraska, Kansas, and Iowa (Pabian } \\
\text { \& Strimple, 1985, and others) }\end{array}$ & & \\
\hline $\begin{array}{l}\text { Mississippian } \\
\text { (Lower Carbon- } \\
\text { iferous) }\end{array}$ & $\begin{array}{l}\text { Alabama (Burdick \& Strimple, 1982) } \\
\text { Indiana, Iowa, Illinois (Ausich \& } \\
\text { Kammer, 1990; Kammer \& Au- } \\
\text { sich, 1992, and others) } \\
\text { Kentucky (Chesnut \& Etlensohn, } \\
\text { 1988; Meyer \& Ausich, 1997, and } \\
\text { others) } \\
\text { Nevada (Webster \& Lane 1987) } \\
\text { Utah and Wyoming (Webster, 1997) }\end{array}$ & & China (Chen \& Yao, 1993) \\
\hline Devonian & $\begin{array}{l}\text { United States (McIntosh, 1984, and } \\
\text { others) }\end{array}$ & $\begin{array}{l}\text { Czech Republic (Prokop \& Petr, 1997, and } \\
\quad \text { others) } \\
\text { France (LeMenn, 1985) } \\
\text { Germany (Hauser, 1997) } \\
\text { Worldwide (Haude, 1992) }\end{array}$ & $\begin{array}{l}\text { Australia (Jell et al., 1988; Jell, 1999) } \\
\text { China (Lane et al., 1997) } \\
\text { South Africa (Jell \& Theron, 1999) }\end{array}$ \\
\hline Silurian & $\begin{array}{l}\text { Iowa (Witzke \& Strimple, 1981) } \\
\text { New York (Brett, 1981; Eckert, } \\
\text { 1984, and others) } \\
\text { Ohio (Ausich, 1984, 1986a, and oth- } \\
\text { ers) } \\
\text { Iowa, Minnesota (Brower, 1996, and } \\
\text { others) }\end{array}$ & Europe (Rozhnov, 1981) & \\
\hline Middle Ordovician & $\begin{array}{l}\text { Oklahoma (Sprinkle, 1982) } \\
\text { Newfoundland (Ausich et al., 1998) } \\
\text { Tennesse (Guensburg, 1984) }\end{array}$ & & \\
\hline Early Ordovician & California (Ausich, 1986b) & Russia (Rozhmov, 1989, 1998) & \\
\hline
\end{tabular}

tions are still in need of study. The immediate challenge for the study of crinoids is to establish a phylogenetic classification for the entire class. Homeomorphy is rampant among the Crinoidea with much of it still unrecognized, and disagreements are present about crinoid origination and early evolution. Both discovery of new faunas in critical intervals and uniform application of various phylogenetic techniques will be needed to sort out the pressing issues and to develop a working consensus. Especially important concerns are homology of aboral cup plates, origination of the Crinoidea, early morphologic diversification, phylogeny of the cladids, and definition and early phylogeny of the Articulata. Molecular techniques should be able to help resolve phylogenetic questions within the articulates, but most major phylogenetic questions are among various Paleozoic groups for which little help can be expected from molecular information.
Alpha taxonomy must still play a vital role in the crinoid research agenda. The current taxonomy of many faunas does not comply with modern species concepts, and a suspicion exists that many genera and species may be incorrectly defined on the basis of geography. Both of these factors preclude asking 21 st century questions of these data. Description of new faunas at critical intervals is essential to learn more about the patterns and processes at macroevolutionary junctures in crinoid history, and new faunas from continents exclusive of North America and Europe will further our global perspective on the evolution of the Crinoidea.

The next generation of advances in macroevolution and evolutionary paleoecology will not occur until a well-tested phylogenetic classification is established. However, with a well-constrained phylogenetic classification, the significance of future crinoid studies is considerable, both for understanding the evolutionary history of 
crinoids and for understanding Phanerozoic benthic communities in general. This promise is a function of the fact that the crinoid data set is unique in many respects as compared to other invertebrates. First, because of the rapid disarticulation of dead crinoids, faunas with complete or nearly complete specimens are typically preserved on smothered sea bottoms, so taphonomic problems, time-averaging concerns, etc. are manageable. The record of crinoid crowns is a series of these data-rich occurrences. Second, unlike most invertebrate fossils, a major part of the food-gathering apparatus, the arms, is commonly preserved on crinoids. Thus, crinoid paleontologists can make direct inferences on the feeding ecology of ancient crinoids. The trophic history of the Crinoidea is well preserved in the fossil record. Third, crinoids typically occupy the highest tier in epifaunal communities, thus the overall tiering structure (Ausich and Bottjer, 2001) of epifaunal suspension-feeding communities can be delineated using crinoids. Finally, despite the strict preservational requirements for complete crinoid preservation, well-preserved crinoid faunas are relatively common through the Phanerozoic. These unique aspects of the crinoid fossil record insure that crinoid paleontology is not insular. Understanding the evolutionary patterns and interpreting the processes responsible for these patterns will lead to fundamental advances that will help delineate the evolutionary history of shallow-water, epifaunal, suspension-feeding communities from the Early Ordovician through at least the Early Cretaceous. It is also a window into understanding the micro- and macroevolutionary importance of trophic evolution that is typically unavailable among benthic invertebrates.

Within the context of evolutionary paleoecology, will it be possible to better identify factors responsible for the turnover of crinoid evolutionary faunas? Will collaboration with other geologists, such as sedimentary isotope geochemists or paleoceanographers, provide the necessary insight and data? Will improved classification schemes allow better understanding of extinction and radiation events?

Will we make strides in analysis of functional morphology by creating virtual crinoids rather than analog models in flumes? For example, current morphometric techniques have been used to create computer animations of the skeleton of Triceratops, and even flesh out the bones with muscle and integument to show their function while walking (Chapman et al., 1999; Perkins, 2000; Walters et al., 2000). Might it be possible with current or future computer hardware and software to recreate crinoid assemblages on a virtual sea floor to test the fluid dynamics and feeding efficiencies of Paleozoic crinoids? Might we be able to model the preferred conditions of different types of calyx and arm structures and learn more about niche differentiation of long extinct animals? For example, could we determine why both the robustplated camerates and the gracile cladids were so diverse during the Mississippian?

We need a better understanding of crinoid biogeography. Certainly crinoids lived on a worldwide basis during the Phanerozoic, yet Paleozoic crinoids are best known from North America and Europe, whereas Mesozoic crinoids are best known in Europe. How much of this is real and how much is a function of where we have looked? In recent years this picture has begun to change with the various frontier work discussed above, but much of Asia, Africa, and South America have yet to be carefully searched for crinoids. This is an important agenda for the 21 st century as we attempt to fill both the temporal and spatial gaps in our knowledge of the fossil record of crinoids.

Our understanding of crinoids increased exponentially during the 20th century. Will it do so again in the 21st? There are many interesting and important questions yet to be adequately addressed.

\section{ACKNOWLEDGMENTS}

We would like to thank R. Brown for help with reference materials and citations and J. C. Brower and T. E. Guensburg for the helpful reviews of this manuscript.

\section{REFERENCES}

AmemiYA, S., AND T. OJI. 1992. Regeneration in sea lilies. Nature, 357 : 546-547.

AmÉzIANE, N. 1997. Echinodermata Crinoidea: Les Pentacrines récoltées lors de la campagne KARUBAR en Indonésie, p. 627-667. In A. Crosnier and P. Bouchet (eds.), Résultats des Campagnes MUSORSTOM. Volume 16. Mémoires de Muséum National d'Histoire Naturelle, 172.

ARENDT, Y. A. 1976. Ordovikskie iglokozhie Gemistreptokrinoidei (Ordovician echinoderms Hemistreptocrinoidea). Moskovskoe Obshchestvo Ispytatelei Prirody, Byulletin Otdel Geologischeski, 51:63-84.

Arendt, Y. A., AND R. T. Hecker. 1964. Klass Crinoidea. Morskie lilii. Sistematitcheskaia tchasti (Class Crinoidea. Crinoids. Systematic part), p. 76-105, 214-231. In Y. A. Orlov (ed.), Osnovyi Paleontologii, Iglokozhi, Gemikhordovye, Pogonofory, i Shchetinkochelyustnye (Fundamentals of Paleontology, Echinodermata, Hemichordata, Pogonophora, and Chaetognatha). Moscow, Izdatelstvo Nedra.

ARENDT, Y. A., AND S. V. RozhnOV. 1995. Concerning hemistreptocrinoids. Paleontological Journal, 29:161-166.

AusICH, W. I. 1980. A model for niche differentiation in Lower Mississippian crinoid communities. Journal of Paleontology, 54:273-288.

AusICH, W. I. 1984. Calceocrinids from the Early Silurian (Llandoverian) Brassfield Formation of southwestern Ohio. Journal of Paleontology, 58:1167-1185.

AusICH, W. I. 1986a. Palaeoecology and history of the Calceocrinidae (Palaeozoic Crinoidea). Palaeontology, 29:85-99.

Ausich, W. I. 1986b. The crinoids of the Al Rose Formation (Early Ordovician, Inyo County, California, USA). Alcheringa, 10:217-224.

Ausich, W. I. 1996. Crinoid plate circlet homologies. Journal of Paleontology, 70:955-964.

AusICH, W. I. 1997. Regional encrinites: A vanished lithofacies, p. 509519. In C. E. Brett, and G. C. Baird (eds.), Paleontological Events: Stratigraphic, Ecologic and Evolutionary Implications. Columbia University Press, New York.

AusICH, W. I. 1998a. Early phylogeny and subclass division of the Crinoidea (Phylum Echinodermata). Journal of Paleontology, 72:499-510.

Ausich, W. I. 1998b. Origin of the Crinoidea, p. 127-132. In R. Mooi and M. Telford (eds.), Echinoderms: San Francisco. Balkema Press, Rotterdam.

Ausich, W. I. 1998c. Phylogeny of Arenig to Caradoc crinoids (Phylum Echinodermata) and suprageneric classification of the Crinoidea. University of Kansas Paleontological Contributions, New Series, 9, 36 p.

Ausich, W. I. 1999. Origin of crinoids, p. 237-242. In M. D. Candia Carnevali and F. Bonasara (eds.), Echinoderm Research 1998. A. A. Balkema, Rotterdam.

Ausich, W. I., AND L. E. BABCOCK. 1998. Phylogenetic position of Echmatocrinus brachiatus, a probable octacoral from the Burgess Shale. Palaeontology, 41:193-202.

Ausich, W. I., And L. E. BABCOCK. 2000. Echmatocrinus, a Burgess Shale animal reconsidered. Lethaia, 33:92-94.

Ausich, W. I., AND T. K. BAUMILlER. 1993. Taphonomic method for determining muscular articulations in fossil echinoderms: a test for the occurrence of muscles in Lower Mississippian cladid crinoids. Palaios, 8:477-484.

Ausich, W. I., AND D. J. BotTJER. 1982. Tiering in suspension-feeding communities on soft substrata throughout the Phanerozoic. Science, 216:173-174.

Ausich, W. I., AND D. J. BotTJER. 2001 (in press). Sessile invertebrates, p. 384-386. In D. E. Briggs and P. R. Crowther (eds.), Palaeobiology II. Blackwell Scientific Publications, Ltd., London.

Ausich, W. I., AND T. W. KAMMER. 1990. Systematics and phylogeny of the late Osagean and Meramecian crinoids Playcrinites and Eucladocrinus from the Mississippian stratotype region. Journal of Paleontology, 64:759-778.

Ausich, W. I., And G. D. Sevastopulo. 1994. Taphonomy of Lower Carboniferous crinoids from the Hook Head Formation, Ireland. Lethaia, 27:245-256. 
Ausich, W. I., T. E. Bolton, L. M. Cumming. 1998. Whiterockian (Ordovician) crinoid fauna from the Table Head Group, western Newfoundland (Canada). Canadian Journal of Earth Sciences, 35:121-130.

Ausich, W. I., T. W. Kammer, And T. K. Baumiller. 1994. Demise of the middle Paleozoic crinoid fauna: a single extinction event or rapid faunal turnover? Paleobiology, 20:345-361.

Ausich, W. I., T. W. Kammer, AND N. G. LANe. 1979. Fossil communities of the Borden (Mississippian) delta in Indiana and northern Kentucky. Journal of Paleontology, 53:1181-1196.

Bassler, R. S., AND M. W. Moodey. 1943. Bibliographic and faunal index of Paleozoic pelmatozoan echinoderms. Geological Society of America Special Paper, 45, $734 \mathrm{p}$.

BAtes, D. E. B. 1968. On 'Dendrocrinus' cambriensis Hicks, the earliest known crinoid. Palaeontology, 11:406-409.

Bather, F. A. 1890a. British fossil crinoids. Annals and Magazine of Natural History, series 6, 5:310-334.

BAther, F. A. 1890b. British fossil crinoids. Annals and Magazine of Natural History, series 6, 5:373-388, 485-486.

BAtHeR, F. A. 1891. Some alleged cases of misrepresentation. Annals and Magazine of Natural History, series 6:480-489.

BAther, F. A. 1893. The Crinoidea of Gotland, P. 1, The Crinoidea Inadunata. Kongl. Svenska Vetenskaps-Akademiens, Handlingar. Stockholm, 25(2):1-182.

BATHER, F. A. 1898. Wachsmuth and Springer's classification of crinoids. Natural Science, 12:337-345.

BATHER, F. A. 1898-1899. Wachsmuth and Springer's monograph on crinoids. Geological Magazine, new series, decade 4, (1898), First Notice, 276-283; Second Notice, 318-329; Third Notice, 419-428; Fourth Notice, 522-527; 6 (1899), Fifth Notice, 32-44; Sixth Notice, 117-127.

Bather, F. A. 1899. A phylogenetic classification of the Pelmatozoa. British Association for the Advancement of Science Report (1898): 916-923.

BAther, F. A. 1900a. The Crinoidea, p. 94-204. In E. R. Lankester (ed.), A Treatise on Zoology. Adam and Charles Black, London.

BATHER, F. A. 1900b. Pores in the ventral sac of fistulate crinoids. American Geologist, 26:307-312.

BAUMILLER, T. K. 1993. Survivorship analysis of Paleozoic Crinoidea: effect of filter morphology on evolutionary rates. Paleobiology, 19: 304-321.

BAUMILLER, T. K., AND W. I. AUSICH. 1992. The "broken stick" model as a null hypothesis for crinoid stalk taphonomy and as a guide to the distribution of connective tissues in fossils. Paleobiology, 18:288-298.

BAumiller, T. K., AND A. GAŹDZICKI. 1996. New crinoids from the Eocene La Meseta Formation of Seymour Island, Antarctica Peninsula, p. 101-116. In A. Gaździcki (ed.), Palaeontological Results from the Polish Antarctic Expeditions, Pt. II, Palaeontologica Polonica, 55.

BAUmiller, T. K., AND J. D. WoOdLey. 1991. Ecology and functional morphology of the isocrinid Cenocrinus asterius (Linnaeus) (Echinodermata: Crinoidea): in situ and laboratory experiments and observations. Bulletin of Marine Science, 48:431-448.

Baumiller, T. K., G. Llewellyn, C. Messing, and W. I. Ausich. 1995. Taphonomy and autotomy of isocrinid stalks. Palaios, 10:87-95.

BIESE, W. 1934. Crinoidea triadica, 255 p. In W. Quenstedt (ed.), Fossilium Catalogus I. Animalia, pars 66. W. Junk, s'Gravenhage.

BIESE, W. 1935-1937. Crinoidea jurassica, 739 p. In W. Quenstedt (ed.), Fossilium Catalogus I. Animalia, pars 70, 73, 76. W. Junk, s'Gravenhage.

Biese, W., AND H. Sieverts-Doreck. 1937. Crinoidea creatcea, 254 p. In W. Quenstedt (ed.), Fossilium Catalogus I. Animalia, pars 77. W. Junk, s'Gravenhage.

BIESE, W., AND H. SiEVERTS-DoReCK. 1939a. Crinoidea caenozoica, 151 p. In W. Quenstedt (ed.), Fossilium Catalogus I. Animalia, pars 80. W. Junk, s'Gravenhage.

Biese, W., AND H. Sieverts-Doreck. 1939b. Supplementum ad Crinoidea triadica, jurassica, cretacea et caenozoica, 81 p. In W. Quenstedt (ed.), Fossilium Catalogus I. Animalia, pars 88. W. Junk, s'Gravenhage.

Blythe Cain, J. D. 1968. Aspects of the depositional environment and palaeoecology of crinoidal limestones. Scottish Journal of Geology, 4: 191-208.

Bourseau, J.-P., AND M. Roux. 1989. Echinodermes: Crinoïdes Pentacrinidae (MUSORSTOM 2 \& CORINDON 2), p. 113-201. In J. Forest (ed.), Résultats des Campagnes MUSORSTOM. Volume 12. Mémoires de Muséum National d'Histoire Naturelle, 143.

Breimer, A. 1962. A monograph of Spanish Palaeozoic Crinoidea. Overdruk uit Leidse Geologische Mededelingen, Deel, 27, 189 p.

BRETT, C. E. 1981. Systematics and paleoecology of Late Silurian (Wenlockian) calceocrinid crinoids from New York and Ontario. Journal of Paleontology, 55:145-175.

BRETT, C. E. 1985. Pelmatozoan echinoderms on Silurian bioherms in western New York and Ontario. Journal of Paleontology, 59:820-838.

Brett, C. E., H. A. Moffat, AND W. L. TAYlor. 1997. Echinoderm taphonomy, taphofacies, and Lagerstätten. Paleontological Society Papers, 3:147-190.

Brett, C. E., T. J. Frest, J. Sprinkle, and C. R. Clement. 1983. Coronoidea: a new class of blastozoan echinoderms based on taxonomic reevaluation of Stephanocrinus. Journal of Paleontology, 57:627651.

BRoILI, F. 1921. Suborder Unitacrinacea, p. 186. In K. A. von Zittel, Grundzüge der Paläontologie (Paläozoologie) (fifth edition). R. Oldenbourg, München and Berlin.

BROADHEAD, T. W. 1981. Carboniferous camerate crinoid subfamily, Dichocrininae. Palaeontographica, Abteilung A, 176:81-157.

Brower, J. C. 1973. Crinoids from the Girardeau Limestone (Ordovician). Palaeontographica Americana, 7(46):263-499.

BROWER, J. C. 1974. Ontogeny of camerate crinoids. University of Kansas Paleontological Contributions Paper, 72, 53 p.

BRower, J. C. 1996. Carabocrinid crinoids from the Upper Ordovician of northern Iowa and southern Minnesota. Journal of Paleontology, 71: 442-458.

Brower, J. C., AND J. Veinus. 1974. Middle Ordovician crinoids from southwestern Virginia and eastern Tennessee. Bulletins of American Paleontology, 66, $125 \mathrm{p}$.

BRower, J. C., AND J. VeINus. 1978. Middle Ordovician crinoids from the Twin Cities area of Minnesota. Bulletins of American Paleontology, 74(304):371-506.

Burdick, D. W., AND H. L. StRIMPLE. 1982. Genevievian and Chesterian crinoids of Alabama. Geological Survey of Alabama Bulletin, 121, 277 p.

Burke, J. J. 1968. Pachylocrinids from the Conemaugh Group, Pennsylvanian. Kirklandia, 3:1-18.

BuRKE, J. J. 1973. Four new pirasocrinid crinoids from the Ames Limestone, Pennsylvanian, of Brooke County, West Virginia. Annals of the Carnegie Museum, 44:157-169.

Candia Carnevalli, M. D., E. Lucca, and F. Bonasora. 1993. Mechanisms of arm regeneration in the feather star Antedon mediterranea: Healing of wound and early stages of development. Journal of Experimental Zoology, 267:299-317.

Chapman, R. E., A. F., Andersen, and S. J. Jabo. 1999. Construction of the virtual Triceratops: procedures, results, and potentials. Journal of Vertebrate Paleontology, 19; 3, Supplement, p. 58.

Chen, Z., AND J. YAO. 1993. Palaeozoic echinoderm fossils of western Yunnan, China. Geological Publishing House, Beijing, 102 p.

Chesnut, D. R., JR., AND F. R. EtTensohn. 1988. Hombergian (Chesterian) echinoderm paleontology and paleoecology, south-central Kentucky. Bulletins of American Paleontology, 95, $102 \mathrm{p}$.

Clark, A. H. 1908. Description of new species of crinoids, chiefly from the collections made by U.S. Fisheries steamer "Albatross" at the $\mathrm{Ha}-$ waiian Islands in 1902; with remarks on the classification of the Comatulida. Proceedings of the U.S. National Museum, 34:209-239.

Clark, A. H. 1911. On a collection unstalked crinoids made by United States Fisheries steamer "Albatross" in the vicinity of the Philippine Islands. Proceedings of the U.S. National Museum, 39:529-563.

Clark, A. H. 1915. A monograph of existing crinoids. U.S. National Museum Bulletin, 82(1), The Comatulids, Pt. 1, 406 p.

Clark, A. H. 1931. A monograph on existing crinoids. I(3) Superfamily Comasterida. U.S. National Museum Bulletin, 82(3):1-816.

Clark, A. H., and A. M. Clark. 1967. A monograph of the existing crinoids. U.S. National Museum, Bulletin 82, Volume 1, The Comatulids, Pt. 5, p. 1-860.

ClARK, H. L. 1916. Report on the sea-lilies, starfishes, brittle-stars and sea urchins obtained by the F. I. S. "Endeavour" on the coasts of Queensland, New South Wales, Tasmania, Victoria, South Australia, and Western Australia. Biological Results Fishing Experiments, F. I. S. "Endeavour" 1909-1914, 4:1-123.

ConAn, G., M. Roux, AND M. SiBUEt. 1981. A photographic survey of 
a population of the stalked crinoid Diplocrinus (Annacrinus) wyvillethomsoni (Echinodermata) from the bathyal slope of the Bay of Biscay. Deep-Sea Research, 28A:441-453.

CONWAy Morris, S. 1993. The fossil record and the early evolution of the Metazoa. Nature, 361:219-225.29:A-341.

David, B., B. Lefebvre, R. Mooi, And R. Parsley. 2000. Are homalozoans echinoderms? An answer from the extraxial-axial theory. Paleobiology, 26:529-555.

DöDERLEIN, L. 1907. Die gestielten Crinoiden der Siboga-Expedition: Siboga Expedite: Uitkomsten op zoologisch, botanisch, oceanographisch en geologisch Gebied, verzameld in Nederlandsch Oost-Indie 1899-1900, 42a, 54 p.

Donovan, S. K. 1986. Pelmatozoan columnals from the Ordovician of the British Isles, Pt. I, Palaeontographical Society Monographs, London, 138 (no. 568):1-68.

Donovan, S. K. 1988. The early evolution of the Crinoidea, p. 236-244. In C. R. C. Paul and A. B. Smith (eds.), Echinoderm Phylogeny and Evolutionary Biology. Oxford University Press, Oxford.

Donovan, S. K. 1989. The significance of the British Ordovician crinoid fauna. Modern Geology, 13:243-255.

Donovan, S. K. 1994. The Late Ordovician extinction of the crinoids in Britain. National Geographic Research and Exploration, 10:72-79.

Donovan, S. K. 1995. Fossils explained, 15: Paleozoic crinoids. Geology Today, 11:196-199.

Donovan, S. K., And C. Franzén-Bengtson. 1988. Myelodactylid crinoid columnals from the Lower Visby Beds (Llandoverian) of Gotland. Geologiska Föreningens i Stockholm Förhandlingar, 110:69-79.

ECKERT, J. D. 1984. Early Llandovery crinoids and stelleroids from the Cataract Group (Lower Silurian), southern Ontario, Canada. Royal Ontario Museum Life Sciences Contributions, 137, 83 p.

ECKERT, J. D. 1988. Late Ordovician extinction of North American and British crinoids. Lethaia, 21:147-167.

Foote, M. 1995. Morphological diversification of Paleozoic crinoids. Paleobiology, 21:273-299.

Foote, M. 2000. Morphological diversity in the evolutionary radiation of Paleozoic and post-Paleozoic crinoids. Paleobiology 25 (supplement to number 2), $115 \mathrm{p}$.

Fujita, T., S. OHTA, AND T. OJI. 1987. Photographic observations of the stalked crinoid Metacrinus rotundus Carpenter in Suruga Bay, central Japan. Journal of the Oceanographical Society of Japan, 43:333-343.

GISLÉN, T. 1922. The crinoids form Dr. S. Bock's expedition to Japan 1914. Nova Acta Regiae Societatis Scientarium Upsaliensis, ser. 4, 5: $1-183$.

Goldring, W. 1923. The Devonian Crinoids of the State of New York. New York State Museum Memoir 16, 670 p.

Grimmer, J. C., N. D. Holland, AND I. HaYAmi. 1985. Fine structure of the stalk of an isocrinid sea lily (Metacrinus rotundus) (Echinodermata, Crinoidea). Zoomorphology, 105:39-50.

GuensburG, T. E. 1984. Echinodermata of the Middle Ordovician Lebanon Limestone, central Tennessee. Bulletins of American Paleontology, 86(319), 100 p.

Guensburg, T. E., And J. Sprinkle. 1992. Rise of echinoderms in the Paleozoic evolutionary fauna: significance of paleoenvironmental controls. Geology, 20:407-410.

GuensburG, T. E., AND J. Sprinkle. 1997. Rhombiferans are not the ancestors of crinoids. Geological Society of America Abstracts with Program, 29:A-341.

GuensburG, T. E., AND J. SPRINKLE. 1998. The earliest camerate crinoids: new collections from the Early Ordovician of western Utah. Geological Society of America Abstracts with Program, 30:A-30.29: A-341.

Guensburg, T. E., And J. Sprinkle. 2001. Earliest crinoid: new evidence for the origin of the dominant Paleozoic echinoderms. Geology, 29:131-134.

Hagdorn, H. 1988. Ainigmacrinus calyconodalis n.g. n.sp., eine ungewöhnliche Seelilie aus der Obertrias der Dolomiten. Neus Jahrbuch für Geologie und Paläontologie, Monatshefte, 1988:71-96.

HaGdoRN, H. 1993. Encrinus liliiformis Im Trochitenkalk Süddeutschlands, p. 245-260. In H. Hagdorn and A. Seilacher (eds.), Muschelkalk. Schöntaker Symposium 1991, Stuttgart.

Hagdorn, H. 1995. Triassic crinoids. Zentralblatt für Geologie und Paläontologie, 2:1-22.
Haude, R. 1980. Constructional morphology of the stems of Pentacrinitidae, and mode of life of Seirocrinus, p. 17-23. In M. Jangoux (ed.), Proceedings of the European Colloquium on Echinoderms, Brussels. A. A. Balkema, Rotterdam.

Haude, R. 1992. Scyphocrinoiden, die Bojen-Seelilien im Hohen SilurTiefen Devon. Palaeontographica Abteilung A, 222:141-187.

Haugh, B. N. 1973. Water vascular system of the Crinoidea Camerata. Journal of Paleontology, 47:77-90.

Haugh, B. N. 1975a. Digestive and coelomic systems of Mississippian camerate crinoids. Journal of Paleontology, 49:472-492.

Haugh, B. N. 1975b. Nervous systems of Mississippian camerate crinoids. Paleobiology, 1:261-272.

Hauser, J. 1997. Die Crinoiden des Mittel-Devon der Eifler-Kalkmulden. J. Hauser [privately published]; Bonn, 273 p.

Hess, H. 1951. Ein neuer Crinoide aus dem mittleren Dogger der Nordschweiz (Paracomatula helvetica n. gen. n. sp.). Eclogae Geologicae Helvetiae, 43:208-216.

Hess, H. 1972. Chariocrinus n. gen. für Isocrinus andreae Desor aus dem unteren Hauptrogenstein (Bajocien) des Basler Juras. Eclogae Geologicae Helvetiae, 65:197-210.

Hess, H. 1983. Balanocrinus berchteni n. sp., un nouveau crinoïde bajocien des Préakoes médianes fribourgeoises. Eclogae Geologicae Helvetiae, 76:691-700.

Hess, H., W. I. Ausich, C. E. Brett, and M. J. Simms. 1999. Fossil Crinoids. Cambridge University Press, Cambridge, 316 p.

Holland, N. D., AND J. C. GRIMmer. 1981. Fine structure of the cirri and a possible mechanism for their motility in stalkless crinoids (Echinodermata). Cell Tissue Research, 214:207-217.

HolterhöFF, P. F. 1996. Crinoid biofacies in Upper Carboniferous cyclothems, midcontinent North America: faunal tracking and the role of regional processes in biofacies recurrence. Palaeogeography, Palaeoclimatology, Palaeoecology, 127:47-81.

JAEKel, O. 1918. Phylogenie und System der Pelmatozoen. Paläontologische Zeitschrift, 3:1-128.

JAGT, J. W. M. 1995. Late Cretaceous and early Cenozoic crinoid assemblages from northeast Belgium and the southeast Netherlands, p. 185196. In R. Emson, A. Smith, and A. Campbell (eds.), Echinoderm Research 1995. A. A. Balkema, Rotterdam.

JAGT, J. W. M. 1999. Late Cretaceous-Early Palaeogene echinoderms and the K/T boundary in the southeast Netherlands and northeast Belgium-Part 1: Introduction and stratigraphy;-Part 2: Crinoids. Scripta Geologica, 116, 255 p.

JELL, P. A. 1999. Silurian and Devonian crinoids from central Victoria. Memoirs of the Queensland Museum, 43:1-114.

Jell, P. A., AND J. N. ThERON. 1999. Early Devonian echinoderms from South Africa. Memoirs of the Queensland Museum, 43:115-199.

Jell, P. A., AND R. J. WiLlinK. 1993. Early Permian cladid crinoids from the Gharif Formation of Oman. Memoirs of the Association of Australian Paleontologists, 15:305-312.

Jell, P. A., J. S. Jell, B. D. Johnson, R. Mawson, and J. A. Talent. 1988. Crinoids from Devonian limestones of eastern Australia. Memoirs of the Queensland Museum, 25:355-402.

KAMMER, T. W. 1985. Aerosol filtration theory applied to Mississippian deltaic crinoids. Journal of Paleontology, 59:551-560.

Kammer, T. W., AND W. I. Ausich. 1987. Aerosol suspension feeding and current velocities: distributional controls for late Osagean crinoids. Paleobiology, 13:379-395.

Kammer, T. W., AND W. I. Ausich. 1992. Advanced cladid crinoids from the middle Mississippian of the east-central United States: primitivegrade calyces. Journal of Paleontology, 66:461-480.

Kammer, T. W., T. K. BAumiller, AND W. I. Ausich. 1997. Species longevity as a function of niche breadth: evidence from fossil crinoids. Geology, 25:219-222.

Kammer, T. W., T. K. Baumiller, And W. I. Ausich. 1998. Evolutionary significance of differential species longevity in Osagean-Meramecian (Mississippian) crinoid clades. Paleobiology, 24:155-176.

Kelly, S. M. 1982. Origin of the crinoid orders Disparida and Cladida: possible inadunate cup plate homologies. Third North American Paleontological Convention Proceedings, 1:285-290.

Kelly, S. M. 1986. Classification and evolution of class Crinoidea. Abstracts of the 4th North American Paleontological Convention:A23.

Kesling, R. V. 1965. Proctothylacocrinus esseri, a new crinoid from the 
Middle Devonian Silica Formation of northwestern Ohio. University of Michigan Museum of Paleontology Contributions, 20:75-87.

Kesling, R. V., AND L. W. MinTz. 1963. Species of the crinoid Dolatocrinus from the Middle Devonian Dock Street Clay of Michigan. University of Michigan Museum of Paleontology Contributions, 18: 67-100.

KIRK, E. 1938. Five new genera of Carboniferous Crinoidea Inadunata. Journal of the Washington Academy of Sciences, 28(4):158-172.

KLIKUSHIN, V. G. 1987. Thiolliericrinid crinoids from the Lower Cretaceous of Crimea. Geobios, 20:625-665.

KuIKushin, V. G. 1996. Late Jurassic crinoids from Sudak environs (Crimea). Palaeontographica Abteilung A, 238:97-151.

KосH, D. L. 1962. Isocrinus from the Jurassic of Wyoming. Journal of Paleontology, 36:1313-1318.

KolatA, D. R. 1975. Middle Ordovician echinoderms from northern Illinois and southern Wisconsin. Journal of Paleontology, Memoir 7, 49(supplement), $74 \mathrm{p}$.

Kristen-Tollmann, E. 1990. Mikrocrinoiden aus der Obertrias der Tethys. Geologisch-Paläontologische Mitteilungen Innsbruck, 17:51-100.

LANE, N. G. 1963. The Berkeley crinoid collection from Crawfordsville, Indiana. Journal of Paleontology, 37:1001-1008.

LANe, N. G. 1970. Lower and Middle Ordovician crinoids from westcentral Utah. Brigham Young University Geology Studies, 17:3-17.

Lane, N. G. 1972. Synecology of Middle Mississippian (Carboniferous) crinoid communities in Indiana. $24^{\text {th }}$ International Geological Congress, Section, 7:89-94.

LANE, N. G. 1973. Paleontology and paleoecology of the Crawfordsville fossil site (Upper Osagian: Indiana). University of California Publications in Geological Sciences, 99:141 p.

Lane, N. G. 1978. Historical review of classification of Crinoidea, p. T348-T359. In R. C. Moore and C. Teichert (eds.), Treatise on Invertebrate Paleontology, Pt. T, Echinodermata 2(2).

Lane, N. G. 1979. Upper Permian crinoids from Djebel Tebaga, Tunisia. Journal of Paleontology, 53:121-132.

Lane, N. G., And G. D. Sevastopulo. 1982. Microcrinoids from the Middle Pennsylvanian of Indiana. Journal of Paleontology, 56:103115.

Lane, N. G., And G. D. Webster. 1966. New Permian crinoid fauna from southern Nevada. University of California Publications in Geological Sciences, 63, $86 \mathrm{p}$.

Lane, N. G., J. A. Waters, and C. G. Maples. 1997. Echinoderm faunas of the Hongguleleeng Formation, Late Devonian (Famennian), Xinjiang-Uygur Autonomous Region, People's Republic of China. Paleontological Society Memoir 47, (Journal of Paleontology, 71(2) supplement), $43 \mathrm{p}$.

LAUDON, L. R. 1973. Stratigraphic crinoid zonation in Iowa Mississippian rocks. Proceedings of the Iowa Academy of Science, 80:25-33.

Laudon, L. R., AND B. H. Beane. 1937. The crinoid fauna of the Hampton Formation at LeGrand, Iowa. University of Iowa Studies in Natural History, 17(6):227-272.

Laudon, L. R., J. M. Parks, And A. C. Spreng. 1952. Mississippian crinoid fauna from the Banff Formation, Sunwapta Pass, Alberta. Journal of Paleontology, 26:544-575.

LeMenn, J. 1985. Les crinoïdes du Dévonien Inférieur et Moyen du Massif Armoricain. La Société géologique et minéralogique de Bretagne Mémoires, 30, 268 p.

LEFELD, J. 1958. Dadocrinus gundeyi Lagenhan (Crinoidea) z Triasu Wierchowego Tatr. Acta Palaeontologica Polonica, 3:59-74.

LEWIS, R. D. 1980. Taphonomy, p. 27-39. In T. W. Broadhead and J. A. Waters (eds.), Echinoderms: Notes for a Short Course. University of Tennessee, Department of Geological Sciences, Studies in Geology, 3.

Lewis, R. D., C. R. Chambers, And M. W. Peebles. 1990. Grain morphologies and surface textures of Recent and Pleistocene crinoid ossicles, San Salvador, Bahamas. Palaios, 5:570-579.

LIDDELL, W. D. 1975. Recent crinoid biostratinomy. Geological Society of America Abstracts with Programs, 7:1169.

McIntosh, G. C. 1979. Abnormal specimens of the Middle Devonian crinoid Bactrocrinites and their effect on the taxonomy of the genus. Journal of Paleontology, 53:18-28.

McIntosh, G. C. 1984. Devonian cladid inadunate crinoids: Family Botryocrinidae Bather, 1899. Journal of Paleontology, 58:1260-1281.

McINTOSH, G. C. 1986. Phylogeny of the dicyclic inadunate crinoid order
Cladida. Fourth North American Paleontological Convention Abstracts: A31.

MACURDA, D. B., JR. 1973. Ecology of comatulid crinoids at Grand Bahama Island. Hydro-lab Journal, 2:9-24.

MACURDA, D. B., JR., AND D. L. MeYer. 1974. Feeding posture of modern stalked crinoids. Nature, 247:394-396.

MacurdA, D. B., JR., AND D. L. Meyer. 1975. The microstructure of the crinoid endoskeleton. University of Kansas Paleontological Contributions Paper, 74, 22 p.

Macurda, D. B., JR., AND D. L. Meyer. 1976. The identification and interpretation of stalked crinoids (Echinodermata) from deep-water photographs. Bulletin of Marine Science, 26:205-215.

Macurda, D. B., JR., AND D. L. MeYer. 1981. The skeletal morphology of the isocrinid crinoids Annacrinus wyvillethomsoni and Diplocrinus maclearanus. University of Michigan Museum of Paleontology Contributions, 25:169-219.

Magnus, D. B. E. 1963. Der Federstern Heterometra savignyi im Roten Meer Natur und Museum, 93:355-368.

MAGNus, D. B. E. 1967. Ecological and ethological studies and experiments of the echinoderms of the Red Sea. Studies in Tropical Oceanography, 5:635-664.

ManNi, R., U. Nicosia, AND B. Riou. 1985. Rhodanometra lorioli $\mathrm{n}$. gen. n. sp. and the other Callovian crinoids from La Voulte-sur-Rhône (Ardéche, France). Estratto da Geologica Romana 24:87-100.

Messing, C. G., M. C. RoseSmyth, S. R. Mailer, and J. E. Miller 1988. Relocation movement in a stalked crinoid (Echinodermata). Bulletin of Marine Science, 42:480-487.

Messing, C. G., A. C. Neumann, And J. C. Lang. 1990. Biozonation of deep-water lithoherms and associated hardgrounds in the northeastern Straits of Florida. Palaios, 5:15-33.

MeYER, D. L. 1971. Post-mortem disintegration of Recent crinoids and ophiuroids under natural conditions. Geological Society of America Abstracts with Programs, 3:645-646.

Meyer, D. L. 1973a. Feeding behavior and ecology of shallow-water unstalked crinoids (Echinodermata) in the Caribbean Sea. Marine Biology, 22:105-130.

MEYER, D. L. 1973b. Distribution and living habits of comatulids near Discovery Bay, Jamaica. Marine Science Bulletin, 23:244-259.

MEYER, D. L. 1979. Length and spacing of the tube feet in crinoids (Echinodermata) and their role in suspension-feeding. Marine Biology, 51:361-369.

MeYeR, D. L., AND W. I. Ausich. 1997. Morphological variation within and among populations of the camerate crinoid Agaricocrinus (Lower Mississippian, Kentucky and Tennessee): breaking the spell of the mushroom. Journal of Paleontology, 71:896-917.

MeYer, D. L., AND D. B. MacurdA, JR. 1977. Adaptive radiation of the comatulid crinoids. Paleobiology, 3:74-82.

MeYer, D. L., AND D. B. MacuRdA, JR. 1980. Ecology and distribution of the shallow-water crinoids of Palau and Guam. Micronesica, 16:5999.

Meyer, D. L., AND K. B. MeYer. 1986. Biostratinomy of Recent crinoids (Echinodermata) at Lizard Island, Great Barrier Reef, Australia. Palaios, 1:294-302.

MeYER, D. L., AND T. OJI. 1993. Eocene crinoids from Seymour Island, Antarctic Peninsula: Paleobiogeographic and paleoecologic implications. Journal of Paleontology, 67:250-257.

Meyer, D. L., W. I. Ausich, And R. E. Terry. 1989. Comparative taphonomy of echinoderms in carbonate facies of the Fort Payne Formation (Lower Mississippian) of Kentucky and Tennessee. Palaios, 4: $533-552$.

Meyer, D. L., C. V. Milsom, And A. J. Webber. 1999. Uintacrinus: A riddle wrapped in an enigma. Geotimes, August:14-16.

MilleR, J. S. 1821. A natural history of the Crinoidea or lily-shaped animals, with observations on the genera Asteria, Euryale, Comatula, and Marsupites. Bryan and Co., Bristol, $150 \mathrm{p}$.

Milsom, C. V. 1994. Saccocoma: a benthic crinoid from the Jurassic Solnhofen Limestone, Germany. Palaeontology, 37:121-129.

Milsom, C. V., M. J. Simms, AND A. S. Gale. 1994. Phylogeny and palaeobiology of Marsupites and Uintacrinus. Palaeontology, 37:595607.

Moore, R. C. 1967. Unique stalked crinoids from Upper Cretaceous of Mississippi. University of Kansas Paleontological Contributions Paper, $17,35 \mathrm{p}$. 
Moore, R. C., AND L. LAudon. 1943. Evolution and classification of Paleozoic crinoids. Geological Society of America Special Paper, 46, $153 \mathrm{p}$.

Moore, R. C., AND R. M. Miller. 1968. Classification and nomenclature of fossil crinoids based on studies of dissociated parts of their columns. University of Kansas Paleontological Contributions, Echinodermata, Article 9, 86 p.

Moore, R. C., And F. B. Plummer. 1940. Crinoids from the Upper Carboniferous and Permian strata in Texas. University of Texas Publication 3945, $468 \mathrm{p}$.

Moore, R. C., And H. L. Strimple. 1973. Lower Pennsylvanian (Morrowan) crinoids from Arkansas, Oklahoma, and Texas. University of Kansas Paleontological Contributions, Echinodermata 12, Article, 60, $84 \mathrm{p}$.

Moore, R. C., And C. Teichert (eds.). 1978. Treatise on Invertebrate Paleontology, Pt. T, Echinodermata 2. Geological Society of America and The University of Kansas Press, Lawrence, 1027 p.

MoOre, R. C., AND H. E. VoKes. 1953. Lower Tertiary crinoids from northwestern Oregon. U.S. Geological Survey Professional Paper, 233E:111-147.

Motsumoto, H. 1929. Outline of a classification of Echinodermata. Science Reports of the Tohoku Imperial University, Sendai, Japan, Second Series (Geology), 8:27-33.

NeKvasillova, O., AND R. PROKOP. 1963. Roveacrinidae (Crinoidea) from the Upper Cretaceous of Bohemia. Ústředního Ústavu Geologického, Věstník, C 38:49-52.

NicosiA, U. 1991. Mesozoic crinoids from the north-western Turkey. Estratto da Geologica Romana, 27:389-436.

OJI, T. 1985. Early Cretaceous Isocrinus from northeast Japan. Palaeontology, 28:629-642.

OJI, T., AND S. AmemiYA. 1998. Survival of crinoid stalk and its taphonomic implications. Paleontological Research, 2:67-70.

Pabian, R. K., AND H. L. Strimple. 1985. Classification, paleoecology, and biostratigraphy of crinoids from the Stull Shale (Late Pennsylvanian) of Nebraska, Kansas, and Iowa. University of Nebraska State Museum Bulletin, 11, $81 \mathrm{p}$.

PECK, R. E. 1943. Lower Cretaceous crinoids from Texas. Journal of Paleontology, 17:451-475.

PECK, R. E. 1948. A Triassic crinoid from Mexico. Journal of Paleontology, 22:81-84.

PECK, R. E. 1955. Cretaceous microcrinoids from England. Journal of Paleontology, 29:1019-1029.

PECK, R. E., AND W. T. WATKIns. 1972. Comatulid crinoids from the Lower Cretaceous of Texas. Journal of Paleontology, 46:410-414.

PERKINS, S. 2000. A makeover for an old friend, time and technology revamp a dinosaur classic. Science News, 158(19):300-302.

PiserA, A., AND J. DZIK. 1979. Tithonian crinoids from Rogoźnik (Plieniny Klippen Belt, Poland) and their evolutionary relationships. Eclogae Geologicae Helvetiae, 72:805-849.

Prokop, R. J. 1970. Family Calceocrinidae Meek \& Worthen, 1869 (Crinoidea) in the Silurian and Devonian of Bohemia. Sborník Geologickych Vĕd Paleontologie, 12:79-134.

Prokop, R. J., AND V. PETR. 1997. The genus Pygmaeocrinus Bouška, 1947 (Crinoidea, Inadunata) in the Devonian of the Barrandian area (Czech Republic). Acta Musei Nationalis Pragae, Series B, Historia Naturalis, 53:1-10.

RamsвotTom, W. H. C. 1961. A monograph on British Ordovician Crinoidea. Palaeontographical Society Monograph, 114, 37 p.

RAsmussen, H. W. 1961. A monograph on the Cretaceous Crinoidea. udgivet af Det Kongelige Danske Videnskabernes Selskabs, Biologiske Skrifter, 12(1), $428 \mathrm{p}$.

Rasmussen, H. W. 1972. Lower Tertiary Crinoidea, Asteroidea, and Ophiuroidea from northern Europe and Greenland. Kongelige Danske Videnskabernes Selskabs, Biologiske Skrifter, 19, 83 p.

Rasmussen, H. W. 1978. Articulata, p. T813-T928. In R. C. Moore and K. Teichert (eds.), Treatise on Invertebrate Paleontology, Pt. T, Echinodermata 2, Geological Society of America and the University of Kansas Press, Lawrence.

Roux, M. 1977. Les Bourgueticrinina du Golfe de Gascogne. Bulletin du Muséum National d'Histoire Naturelle Zoologie, 296:25-82.

Roux, M. 1994. The CALSUB cruise on the bathyal slopes of New Caledonia, p. 9-47. In A. Crosnier (ed.), Résultats des Campagnes
MUSORSTOM. Volume 12. Mémoires du Muséum National d'Histoire Naturelle, 161

Rowe, F. W. E., A. K. Hoggett, R. A. Birtles, and L. L. Vail. 1986. Revision of some comasters genera from Australia (Echinodermata: Crinoidea), with descriptions of two new genera and nine new species. Zoological Journal of the Linnean Society, 86:197-277.

Rozhnov, S. V. 1981. Morskie lilii nadsemeistva Pisocrinacea [The crinoid superfamily Pisocrinacea]. Akademiya Nawk SSSR, Trudy Paleontologicheskogo Institut, 192, 127 p.

RozHNOV, S. V. 1988. Morfologiya i sistematichskoye polozheniye nizhneordovikskikh morskikh liliy. Paleontologicheskii Zhurnal, 2:6779.

Rozhnov, S. V. 1989. The morphology and systematic position of Lower Ordovician sea lilies. Paleontological Journal, 2:62-75.

Rutman, L., AND L. Fishelson. 1969. Food composition and feeding behaviour of shallow-water crinoids at Eliat (Red Sea). Marine Biology, 3:46-57.

SchmidT, W. E. 1934. Die Crinoideen des Rheinischen Devons, Teil 1. Preussischen Geologischen Landesanstalt, Abhandlungen, new series, no. 163,149 p.

SchmidT, W. E. 1942. Die Crinoideen des Rheinischen Devons, Teil 2. Reichsstelle für Bodenforschung, Abhandlungen, new series, no. 182, $253 \mathrm{p}$.

Seilacher, A., G. Drozdzewski, and R. Haude. 1968. Form and function of the stem in a pseudoplanktonic crinoid (Seirocrinus). Palaeontology, 11:275-282.

SeVAstopulo, G. D., AND N. G. LANE. 1988. Ontogeny and phylogeny of disparid crinoids, p. 245-253. In C. R. C. Paul and A. B. Smith (eds.), Echinoderm Phylogeny and Evolutionary Biology. Oxford University Press, Oxford.

SiEverts-Doreck, H. 1951. Cyathidium im Tithon von Mähren? Neues Jarhbuch für Geologie und Paläontologie Abhandlungen, 94:1-4.

Sieverts-Doreck, H. 1952. "Orders of the Articulata," p. 414. In R. C. Moore, C. G. Lalicker, and A. G. Fisher (eds.), Invertebrate Fossils. McGraw-Hill Book Co, Inc., New York.

SIEVERTS-DORECK, H. 1953. Sous-classe 4. Articulata, p. 756-765. In J. Priveteau (ed.), Traité de paléontologie. Volume 3. Masson and Cie, Paris.

SIEVERTS-DorecK, H. 1981. Nachweis von Balanocrinus subteroides, Familie Isocrinidae, im Ober-Pliensbachium der Herforder Liasmulde. Berichte des Naturwissenschaftlichen Vereins für Bielefeld, 177-192.

SiEverts-Doreck, H., AND W. BIESE. 1939. Supplementum ad Crinoidea triadica, jurassica, cretacea et caenozoica, 81 p. In W. Quenstedt (ed.), Fossilium Catalogus I. Animalia, pars 88. W. Junk, s'Gravenhage.

SignOR, P. W., AND G. VERMEIJ. 1994. The plankton and the benthos: origins and early history of an evolving relationship. Paleobiology, 20: 297-319.

SIMms, M. J. 1986. Contrasting lifestyles in Lower Jurassic crinoids: a comparison of benthic and pseudoplanktonic Isocrinida. Palaeontology, 29:475-493.

SIMMS, M. J. 1989. British Lower Jurassic crinoids. Monograph of the Palaeontographical Society, London, 142:1-103.

SIMMS, M. J. 1994. Reinterpretation of thecal plate homology and phylogeny in the class Crinoidea. Lethaia, 26:303-312.

Simms, M. J., And G. D. Sevastopulo. 1993. The origin of articulate crinoids. Palaeontology, 36:91-109.

Simms, M. J., A. S. Gale, P. Gilliland, E. P. F. Rose, and G. D. SeVastopulo. 1993. Echinodermata, p. 491-528. In M. J. Benton (ed.), The Fossil Record 2. Chapman \& Hall, London.

SPRINGER, F. 1900. On the presence of pores in the ventral sac in fistulate crinoids. American Geologist, 26:133-151.

Springer, F. 1913. Crinoidea, p. 173-243. In C. R. Eastman and K. A. von Zittel (eds.), Text-book of Paleontology. Macmillan and Co., London.

SPRINGER, F. 1920. The Crinoidea Flexibilia. Smithsonian Institution, Publication 2501, 486 p.

SPRINKLE, J. (ed.). 1982. Echinoderm faunas from the Bromide Formation (Middle Ordovician) of Oklahoma. The University of Kansas Paleontological Contributions Monograph, 1, 369 p.

SPRINKLE, J., AND D. Collins. 1998. Revision of Echmatocrinus from the Middle Cambrian Burgess Shale of British Columbia. Lethaia, 31: 269-282.

Sprinkle, J., And T. E. GuensburG. 1997. How the crinoid got its cup 
plating: Arm brachials down plus stem (penta) meres up. Geological Society of America Abstracts with Program, 29:A-341.

SPRINKLE, J., AND R. C. MoORE. 1978. Echmatocrinea, p. T405-407. In R. C. Moore and C. Teichert (eds.), Treatise on Invertebrate Paleontology, Pt. T, Echinodermata 2(2). Geological Society of America and University of Kansas Press, Lawrence.

StRImPle, H. L. 1963. Crinoids of the Hunton Group (Devonian-Silurian) of Oklahoma. Oklahoma Geologial Survey Bulletin, 100, 169 p.

StRIMPLE, H. L., AND M. R. MCGinNIS. 1972. A new camerate crinoid from the Al Rose Formation, Lower Ordovician of California. Journal of Paleontology, 46:72-74.

Strimple, H. L., AND R. C. Moore. 1971. Crinoids of the Francis Shale (Missourian) of Oklahoma. University of Kansas Paleontological Contributions Paper, 55, $20 \mathrm{p}$.

Strimple, H. L., AND W. T. Watkins. 1955. New Ordovician echinoderms. 1. Three new genera. Washington Academy of Sciences Journal, 45:347-353.

StukalinA, G. A. 1966. O printsipakh klassifikatsii stebley drevnikh morskikh liliy. Paleontologicheskii Zhurnal, 3:94-102 [On principles on classification of stems of ancient sea lilies].

TAYLOR, W., AND C. E. BRETT. 1996. Taphonomy and paleoecology of echinoderm Lagerstätten from the Silurian (Wenlockian) Rochester Shale. Palaios, 11:118-140.

Teichert, K. 1949. Permian crinoid Calceolispongia. Geological Society of America Memoir, 34, 132 p.

Ubaghs, G. 1953. Classe des Crinoïdes, p. 658-773. In J. Priveteau (ed.), Traité de paléontologie. Volume 3. Masson and Cie, Paris.

Ubaghs, G. 1956. Recherches sur les Crinoïdes Camerata du Silurien de Gotland (Suède) Introduction générale et partie I: Morphologie et Paléobiologie de Barrandeocrinus sceptrum Angelin. Arkiv för Zoologi, 9:515-550

Ubaghs, G. 1969. Aethocrinus moorei Ubaghs, n. gen., n. sp., le plus ancien crinoïde dicylique connu. University of Kansas Paleontological Contributions Paper, 38, 25 p.

Ubaghs, G. 1972. More about Aethocrinus moorei Ubaghs, the oldest known dicyclic crinoid. Journal of Paleontology, 46:773-775.

Ubaghs, G. 1978. Origin of crinoids, p. T275-T281. In R. C. Moore and C. Teichert (eds.), Treatise on Invertebrate Paleontology, Pt. T, Echinodermata 2(2). Geological Society of America and University of Kansas Press, Lawrence.

VAN SANT, J. F., AND N. G. LANE. 1964. Crawfordsville (Indiana) crinoid studies. University of Kansas Paleontological Contributions Echinodermata Article, 7, $136 \mathrm{p}$.

WachSMUth, C., AND F. SPRINGer. 1880. Revision of the Palaeocrinoidae. Proceedings of the Academy of Natural Sciences of Philadelphia for 1879:226-378.

Wachsmuth, C., AND F. SPRINGer. 1881. Revision of the Palaeocrinoidea, Pt. 2, Proceedings of the Academy of Natural Sciences of Philadelphia for 1881:175-411 (1-237).

WachSMUth, C., AND F. SPRINGER. 1885. Revision of the Palaeocrinoidea, Pt. 3, Sec. 1. Proceedings of the Academy of Natural Sciences of Philadelphia for 1885:223-364 (1-139).

Wachsmuth, C., AND F. SPRINGER. 1886. Revision of the Palaeocrinoidae, Pt. 3, Sec. 2. Proceedings of the Academy of Natural Sciences of Philadelphia for 1885:64-226 (140-302).

Wachsmuth, C., AND F. SPRINGer. 1891. The perisomic plates of the crinoids. Proceedings of the Academy of Natural Sciences of Philadelphia for 1890:345-392.

WachSmuth, C., AND F. Springer. 1897. The North American Crinoidea Camerata. Harvard College Museum of Comparative Zoology, Memoir 21-22, $897 \mathrm{p}$

WALters, R. F., R. E. Chapman, AND B. J. Mohn. 2000. Using virtual skeletons as a basis for reconstructing fossil vertebrates. Journal of Vertebrate Paleontology, 20; 3, Supplement, p. 71.
WANNER, J. 1931. Neue Beiträge zur Kenntnis der permischen Echinodermen von Timor, V. Poteriocrinidae, Pt. 1, Nederlandsch-Oost-Indie, Dienst van den Mijnbouw, Wetenschappelijke. Mededeelingen, Den Haag, no. 16 , p. $1-27$.

WANNER, J. 1949. Neue Beiträge zur Kenntnis der permischen Echinodermen von Timor, XVI. Poteriocrinidae, Pt. 4, Palaeontographica, Supplement, 4, 1-56 p.

Webster, G. D. 1973. Bibliography and index of Paleozoic crinoids 1942-1968. Geological Society of America Memoir, 137, 341 p.

Webster, G. D. 1977. Bibliography and index of Paleozoic crinoids 1969-1973. Geological Society of America Microform Publication, 8, $235 \mathrm{p}$.

Webster, G. D. 1986. Bibliography and index of Paleozoic crinoids 1974-1980. Geological Society of America Microform Publication, 16 $405 \mathrm{p}$.

Webster, G. D. 1988. Bibliography and index of Paleozoic crinoids 1981-1985. Geological Society of America Microform Publication, 18, $236 \mathrm{p}$.

Webster, G. D. 1990. New Permian crinoids from Australia. Palaeontology, 33:49-74.

Webster, G. D. 1993. Bibliography and index of Paleozoic crinoids 1986-1990. Geological Society of America Microform Publication 25, $204 \mathrm{p}$.

WebsteR, G. D. 1997. Lower Carboniferous echinoderms from northern Utah and western Wyoming. Utah Geological Survey Bulletin, 128, $65 \mathrm{p}$.

Webster, G. D., AND P. A. Jell. 1992. Permian echinoderms from Western Australia. Memoirs of the Queensland Museum, 32:311-373.

Webster, G. D., AND P. A. Jell. 1993. Early Permian inadunate crinoids from Thailand. Memoirs of the Queensland Museum, 33:349-359.

Webster, G. D., ANd P. A. Jell. 1999. New Permian crinoids from Australia. Memoirs of the Queensland Museum, 43:279-339.

Webster, G. D., and N. G. Lane. 1987. Crinoids from the Anchor Limestone (Lower Mississippian) of the Monte Cristo Group southern Nevada. University of Kansas Paleontological Contributions Paper, $119,56 \mathrm{p}$.

WiLLINK, R. J. 1978. Catillocrinids from the Permian of eastern Australia. Alcheringa, 2:83-102.

WILLINK, R. J. 1979. Some conservative and some highly-evolved Permian crinoids from eastern Australia. Alcheringa, 3:117-134.

Witzke, B. J., AND H. L. StRimple. 1981. Early Silurian camerate crinoids of eastern Iowa. Proceedings of the Iowa Academy of Sciences, 88:101-137.

Wright, J. 1939. The Scottish Carboniferous Crinoidea. Royal Society of Edinburgh, Transactions, 60(1):1-78.

Wright, J. 1950-1960. A monograph of the British Carboniferous Crinoidea. [1950, v. 1 , pt. 1 , i-xxx $+1-24$, pls. $1-7,4$ text-figs.; 1951a v. 1 , pt. 2 , $25-46$, pls. $8-12$, 10 text-figs.; 1951 b, v. 1 , pt. $3,47-102$ pls. 13-31, 27 text-figs.; 1952 , v. 1, pt. 4, 103-148, pls. 32-40, 40 text-figs.; 1954, v. 1 , pt. 5, 149-190, pls. 41-47, 27 text-figs.; 1955a, v. 2 , pt. $1,191-254$, pls. $48-63$, 16 text-figs.; 1955 b, v. 2 , pt. 2,255 272 , pls. $64-67,2$ text-figs.; 1956 , v. 2 , pt. 3, 273-306, pls. $68-75$, 2 text-figs.; 1958 , v. 2, pt. 4, 307-328, pls. 76-81, 4 text-figs.; 1960, v. 2, pt. 5, 329-347, pls. A, B.]. London.

ZiTT, J. 1979. Hemibrachiocrinidae Arendt, 1968 (Crinoidea, Cyrtocrinida) from the Lower Cretaceous of Stramberk (Czechoslovakia). Věstnik Ústředniho ústavu geologického, 54:341-348.

ZITT, J. 1980. Comatulid crinoids from the Lower Cretaceous of Štramberk (Czechoslovakia). Časopis pro mineralogii a geologii, 25:125135.

ZitTel, K. A. von. 1879. Handbuch der Palaeontologie, Band 1, Palaeozoologie, Abt. 1, R. Oldenbourg, München and Leipzig, 765 p.

ZitTel, K. A. von. 1895. Grundzüge der Palaeontologie (Palaeozoologie) (first edition). R. Oldenbourg, München, $971 \mathrm{p}$.

ACCEPTED 5 JUNE 2001 